\title{
INVESTIGATING NOVEL APPROACHES FOR THE INTEGRATED CONTROL OF THE SOILBORNE STRAWBERRY PATHOGENS MACROPHOMINA PHASEOLINA AND FUSARIUM OXYSPORUM f. sp. FRAGARIAE
}

\author{
A Thesis \\ presented to \\ the Faculty of California Polytechnic State University, \\ San Luis Obispo
}

In Partial Fulfillment

of the Requirements for the Degree

Master of Science in Agriculture with Specialization in Plant Protection Science

by

Mel Carter

June 2016 
(C) 2016

Mel Carter

ALL RIGHTS RESERVED 
TITLE: Investigating novel approaches for the integrated control of the soilborne strawberry pathogens Macrophomina phaseolina and Fusarium oxysporum f. sp. fragariae

AUTHOR: Mel Carter

DATE SUBMITTED: June 2016

COMMITTEE CHAIR: Kelly Ivors, Ph.D.

Associate Professor

Horticulture and Crop Science Department

COMMITTEE MEMBER: Lauren Garner, Ph.D.

Professor

Horticulture and Crop Science Department

COMMITTEE MEMBER: Gerald Holmes, Ph.D.

Director

Cal Poly Strawberry Center

COMMITTEE MEMBER: Heather Smith

Senior Lecturer and Statistical Consultant

Statistics Department 


\begin{abstract}
Investigating novel approaches for the integrated control of the soilborne strawberry pathogens Macrophomina phaseolina and Fusarium oxysporum f. sp. fragariae
\end{abstract}

\title{
Mel Carter
}

Macrophomina phaseolina (Mp) and Fusarium oxysporum f. sp. fragariae (Fof) are emerging soilborne pathogens causing crown rot and Fusarium wilt, respectively, in commercial strawberry production in California. Fungicides representing eight active ingredients from four different mode of action groups (FRAC groups 1, 3, 7 and 12) were evaluated for their efficacy against each pathogen in vitro and each disease in planta. Fungicide active ingredients were evaluated for their ability to inhibit mycelial growth of both pathogens in vitro. Half-strength potato dextrose agar was amended with six different concentrations $(0.01,0.1,1.0,5.0,10,50 \mu \mathrm{g}$ a.i./ml $)$ of seven fungicides in FRAC groups 3, 7 and 12. Concentrations that inhibited fungal growth by $75 \%\left(\mathrm{EC}_{75}\right)$ compared to unamended media were determined for two different isolates each of $M p$ and Fof and were used to determine fungicide rates for subsequent in planta studies. Tebuconazole strongly inhibited the mycelial growth of both pathogens (average $\mathrm{EC}_{75}$ for $M p$ was 2.4 ppm; average $\mathrm{EC}_{75}$ for $F$ of was $7.48 \mathrm{ppm}$ ), as did metconazole (average $\mathrm{EC}_{75}$ for $M p$ was $2.53 \mathrm{ppm}$; average $\mathrm{EC}_{75}$ for $F$ of was $\left.1.28 \mathrm{ppm}\right)$. Fludioxonil strongly inhibited mycelial growth of $M p$, but had no impact on the growth of Fof. Penthiopyrad, fluopyram, flutriafol, and flutolanil were less effective at inhibiting fungal growth of either fungus. Greenhouse in planta studies evaluated twenty-four fungicide treatments 
(eight fungicides at low, med and high rates) that were drench applied to infested potting media two days prior to planting of pathogen susceptible strawberry cultivars (San Andreas for $M p$ and Monterey for Fof) and again at day 21. Controls were a noninoculated and an inoculated water-drench treatment. Buried inoculum was recovered at days 2 and 23 and plated on selective media for colony forming unit (CFU) quantification. Plant disease assessments were made each week for 11 weeks. An analysis of variance (ANOVA) of CFUs revealed no significant differences $(p>0.05)$ among treatments and when compared to the non-treated control for both $M p$ and $F o f$, but showed significant decreases ( $\mathrm{p}<0.05$ ) in CFUs between weeks 1 and 3 for both $M p$ and Fof. An ANOVA for disease assessments in the form of area under the disease progress curve (AUDPC) showed significant decreases of disease severity in treatments with penthiopyrad only (low, medium and high rates) $(\mathrm{p}<0.05)$. There were no significant differences ( $p>0.05)$ in AUDPC among treatments and when compared to the noninoculated and no-fungicide controls for $F o f$. The data indicates that these fungicides used alone are not effective against these pathogens in planta.

A strawberry plant extract (germination stimulant) was assessed for its ability to stimulate germination of $M p$ microsclerotia in vitro and in planta. The germination stimulant was applied as a drench at six different concentrations $(0,10,100,1,000$, 10,000 and 30,000 ppm) to soil containing filter disk packets of microsclerotia of $M p$ at day 0 and 14. Filter disk packets were retrieved three days after the drench and microsclerotia were observed microscopically for germination. Results showed that the number of germinating microsclerotia was significantly higher after the application of the germination stimulant compared to non-drench and $0 \mathrm{ppm}$ controls $(\mathrm{p}<0.001)$. 
An integrated container trial was also conducted using the germination stimulant at 10,000 ppm applied three days prior to a fungicide drench with tebuconazole or thiophanate-methyl to determine the effect of fungicides on the germinated microscleotia. The use of the germination stimulant with label rates of the fungicides lowered the number of germinated intact microsclerotia significantly $(\mathrm{p}<0.001)$ especially after two drench applications. The use of the germination stimulant with fungicides could be investigated further as one method for controlling soilborne diseases of strawberry.

Key Words: disease management, Fusarium oxysporum f. sp. fragariae, germination stimulant, Macrophomina phaseolina, methyl bromide alternative, soilborne pathogen, strawberry 


\section{ACKNOWLEDGMENTS}

I want to thank my advisor, Dr. Kelly Ivors, for all of her hard work, encouragement, constructive criticism, and support that helped me in every aspect of this project. Dr. Ivors taught me that being pathological is a good thing and I would not have been able to do complete this degree without her. I also want to thank Dr. Lauren Garner for taking me under her wing at the beginning of my journey and for her constant support. Thank you to Dr. Gerald Holmes for his experience and input in this project and for all of his advice throughout this experience. I am also grateful for Professor Heather Smith and her patience and statistical prowess which was essential to analyzing the complicated data sets we produced. Additionally, I would like to acknowledge Dr. David Headrick, Dr. Mark Shelton, and Dr. Hillary Thomas for their continued support and encouragement in my scientific training and career goals. I could not have completed this degree without the support of my fellow graduate students and the numerous other students who have helped me conduct my experiments in the lab and greenhouse. Additionally, I also want to recognize the California Strawberry Commission, including Dan Legard, for their recognition of my potential and for helping to fund my research. Last, but certainly not least, I want to thank my family. I cannot describe how much your sacrifices and support have meant to me. Conrad, I hope that one day you will understand why I spent so much time at the lab and in the greenhouse as it was all for you, my little man! 


\section{TABLE OF CONTENTS}

\section{Page}

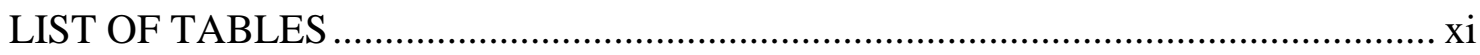

LIST OF FIGURES …........................................................................... xii

\section{CHAPTER}

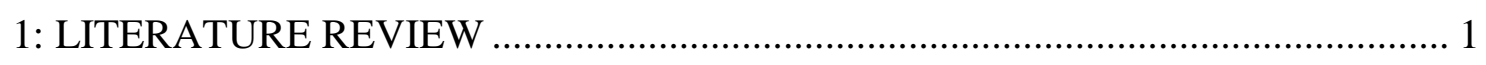

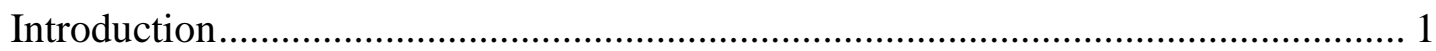

Methyl-bromide \& Other Fumigants ................................................................. 2

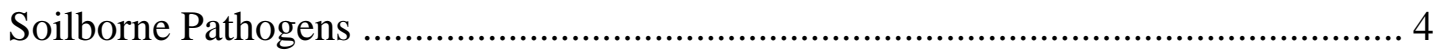

Macrophomina phaseolina ..................................................................... 5

Fusarium oxysporum f. sp. fragariae ........................................................... 6

Spread of the pathogens \& management of the diseases ................................. 7

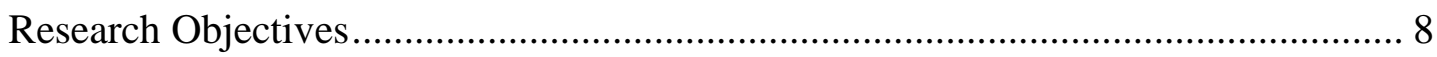

2: EVALUATING THE EFFICACY OF VARIOUS RATES AND TIMING OF SOIL-APPLIED FUNGICIDES FOR MANAGING MACROPHOMINA CROWN ROT AND FUSARIUM WILT ................................................................. 9

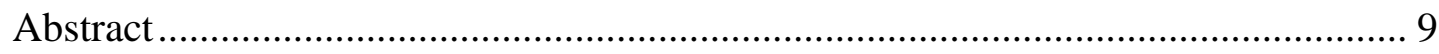

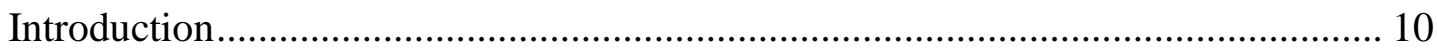

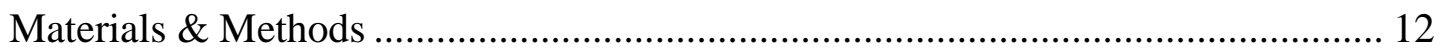

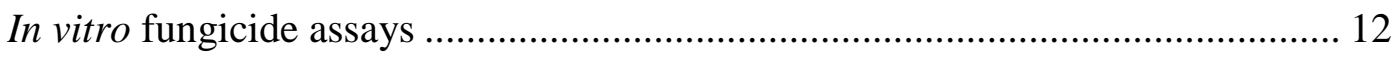

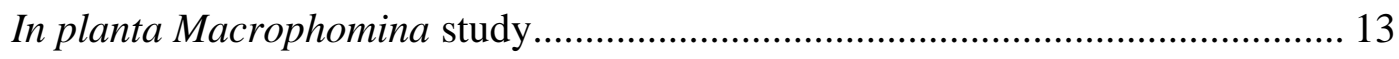

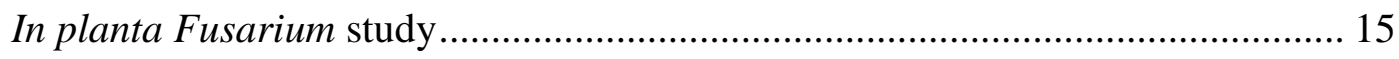


Statistical analysis

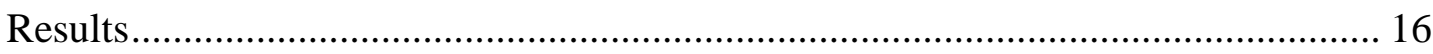

In vitro fungicide assays .............................................................................. 16

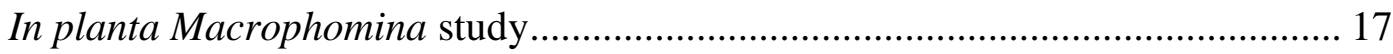

In planta Fusarium study ................................................................................. 19

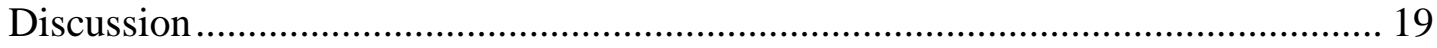

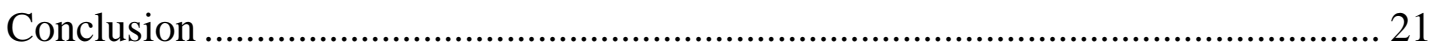

3: EXAMINING THE INFLUENCE OF STRAWBERRY PLANT EXTRACTS ON GERMINATION OF MACROPHOMINA PHASEOLINA MICROSCLEROTIA........ 31

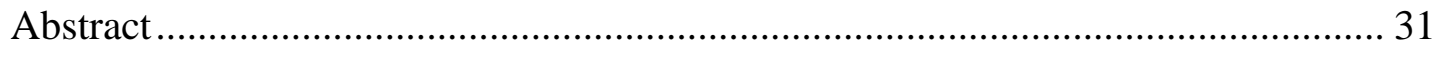

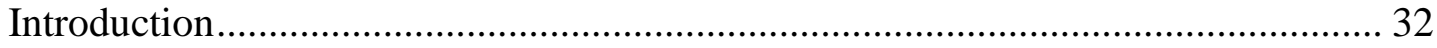

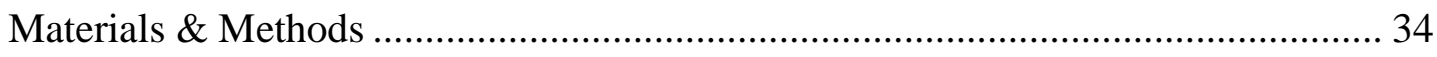

Strawberry plant extract production........................................................................ 34

Macrophomina phaseolina microsclerotia packets .............................................. 34

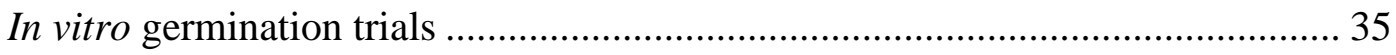

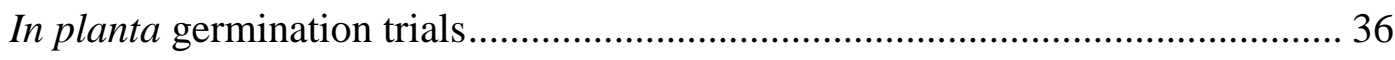

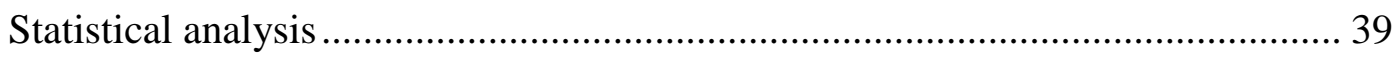

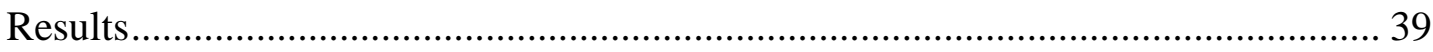

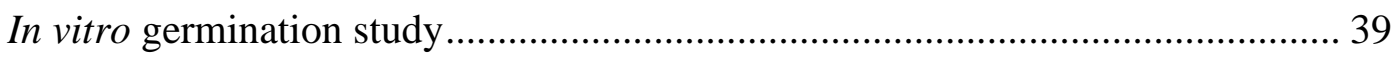

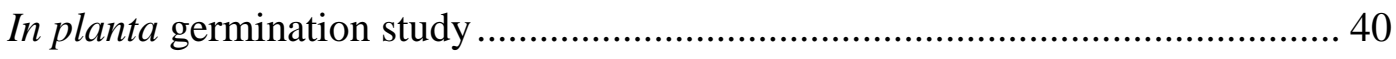

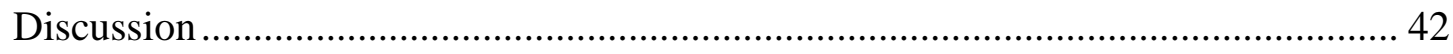




\section{APPENDICES}

Appendix A. Regression Analysis for In Vitro Fungicide Assays ……………….....58

A 1. In vitro fungicide assays for Macrophomina phaseolina (Mp) isolates......... 58

A 2. In vitro fungicide assays for Fusarium oxysporum f. sp. fragariae (Fof)

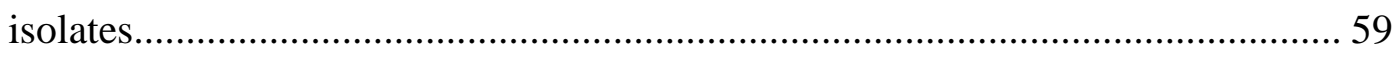

Appendix B. Variance Tables for In Planta Fungicide Studies ................................ 61

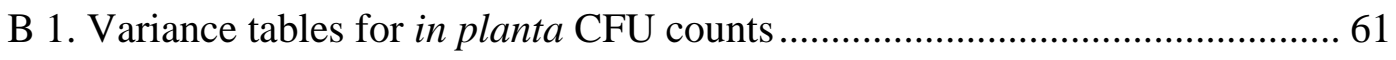

B 2. Variance tables for in planta AUDPC analysis................................................ 62

Appendix C. Data Analysis for Plant Extract Studies .................................................. 63

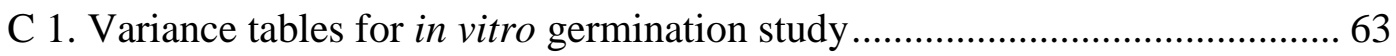

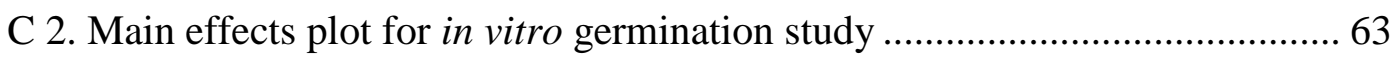

C 3. Variance tables for in planta germination studies........................................... 64 


\section{LIST OF TABLES}

Table

Page

Table 2.1. List of all in planta fungicide treatments............................................. 22

Table 2.2. Mean concentrations of seven fungicides inhibiting mycelial radial growth by $75 \%\left(\mathrm{EC}_{75}\right)$ of Macrophomina phaseolina $(\mathrm{Mp})$ and Fusarium oxysporum f. sp. fragariae (Fof) in Petri dishes. ..................................................... 25

Table 2.3. Percent viable plugs after exposure to active ingredients at day 50........... 26

Table 2.4. Mean Colony Forming Units (CFUs) per plate of inoculum that was buried in bags and received fungicide treatments...

Table 2.5. Number of dead plants confirmed with $M p$ or Fof by direct plating after

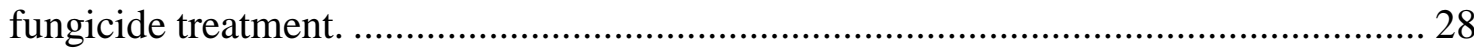

Table 3.1. Timeline of various treatment applications and data collection during the in planta trial.

Table 3.2. Percent of Macrophomina phaseolina microsclerotia that germinated after treatment drench for two repeated trials in vitro.

Table 3.3. Percent of Macrophomina phaseolina microsclerotia that germinated after specific in planta trial treatments.

Table 3.4. Percent of germinated Macrophomina phaseolina microsclerotia with intact mycelium after drenches of plant extracts and fungicides in planta. 


\section{LIST OF FIGURES}

Figure

Page

Figure 2.1. Rating scale guide: (a) no symptoms $=1$, (b) $25 \%$ wilt or necrosis $=2$, (c) $50 \%$ wilt and necrosis $=3$, (d) and (e) $75 \%$ wilt or necrosis $=4$ and (f) $100 \%$ wilt or necrosis $=5$.

Figure 2.2. Mycelial growth of Macrophomina phaseolina on (a) unamended media (maximum colony diameter at day 4), (b) Flutriafol at $1 \mu \mathrm{g} / \mathrm{ml}(1 \mathrm{ppm})$ (maximum colony diameter at day 4), (c) Tebucaonazole at $1 \mu \mathrm{g} / \mathrm{ml}(1 \mathrm{ppm})$ (maximum colony diameter at day 15), and (d) Tebuconazole at $50 \mu \mathrm{g} / \mathrm{ml}$ (50 ppm) (minimal growth at day 50).

Figure 2.3. Median AUDPC for Macrophomina phaseolina in planta fungicide trial II.

Figure 2.4. Mean AUDPC for Fusarium oxysporum f. sp. fragariae in planta fungicide trial I.

Figure 3.1. Microsclerotia of Macrophomina phaseolina that (a) did not germinate, and (b) did germinate

Figure 3.2. Percent of Macrophomina phaseolina microsclerotia that germinated after treatment drench in vitro. 46

Figure 3.3. Percent of Macrophomina phaseolina microsclerotia that germinated after treatment drench in planta.

Figure 3.4. Microsclerotia of Macrophomina phaseolina that (a) did not germinate, and (b) did germinate. Microsclerotia in (c) and (d) did germinate, but the mycelium is no longer intact (red arrows). The mycelium has been stained with $2 \%$ lactophenol blue.

Figure 3.5. Percent of germinated Macrophomina phaseolina microsclerotia with intact mycelium after drenches of plant extracts and fungicides in planta. 


\section{CHAPTER 1: LITERATURE REVIEW}

\section{Introduction}

Strawberry (Fragaria x ananassa Duchesne) production has relied heavily on soil fumigation to effectively control a wide range of economically devastating soilborne diseases. Emphasis on finding non-fumigant disease control measures has become a top priority due to the phase-out of methyl bromide and increasing regulations on other fumigants. Studies have shown that modern strawberry yields are dependent on the preplant reduction of soil pathogens (Fang et al., 2012). Pre-plant fumigation significantly reduces soilborne pathogen populations but does not eliminate them; repeated fumigation for each crop is often necessary to keep pathogens at acceptable levels in annual production systems (Wilhelm and Paulus, 1980).

California produces strawberries on approximately 40,000 acres with a value of over \$2.5 billion annually (California Strawberry Commission, 2015), Fresh berries are grown in three main growing regions: Santa Maria, Oxnard and Salinas/Watsonville, while transplants and genetic material are typically grown at low and high elevation nurseries in the central valley and interior of northern California (California Strawberry Commission, 2015). Fertile soils and mild climates benefit strawberry production in California. The success of the industry can be attributed to intensive breeding programs, both private and public, along with the optimization of planting systems and cultural practices (Voth and Bringhurst, 1990). Since the 1960s, methyl bromide mixed with chloropicrin has been used to control soilborne diseases, leading to an increase in production acreage of strawberries (Fravel et al., 2003). Due to its effect on the environment, methyl bromide has been phased-out in many countries and the U.S. 
requires a critical use exemption as a result of the Montreal Protocol (Shennan et al., 2012; Fang et al., 2012). However, this chemical will be phased out in commercial strawberry production by the end of 2016 (Shennan et al., 2012).

\section{Methyl-bromide \& Other Fumigants}

The implementation of methyl bromide has been the most cost effective tool for producers to control soilborne diseases, insects, and weeds (Shaw and Larson, 1996; Martin, 2003; Yuen et al., 1991). The largest consumers of methyl bromide have historically been tomato and strawberry producers in Florida and California (Shaw and Larson, 1996). The use of methyl bromide began in the 1960s and has been one of the top five most used pesticides in the U.S. (Fravel et al., 2003). The introduction of methyl bromide fumigation in 1961 resulted in consistently higher yields and changed grower practices with the use of drip irrigation and polyethylene films to prevent contact between fruit and soil (Voth and Bringhurst, 1990; Wilhelm and Paulus., 1980).

Methyl bromide mixed with chloropicrin has been used to fumigate most of California strawberry production soils until recently (Wilhelm and Paulus., 1980; De Cal et al., 2004). Methyl bromide is an odorless and colorless gas that is injected about two feet $(0.61 \mathrm{~m})$ below the soil surface as a pre-plant treatment (Leahy et al., 2013). Although the soil is covered with plastic tarps, some methyl bromide dissipates into the atmosphere. Methyl bromide has been implicated in the reduction of the ozone layer leading to increased ultraviolet radiation reaching the earth's surface (US EPA, 1999). The Montreal Protocol resulted in the gradual phase-out of methyl bromide, which began in 1991 and will end in 2016 (US EPA, 1999). On an annual basis, the protocol allows for 
critical use exemptions, mainly applied for by tomato and strawberry producers (Martin, 2003). Since the phase-out, pathogens are becoming established in soil and contribute to reduced yields by lowering plant vigor and causing mortality (Martin, 2003; Shennan et al., 2012).

Alternative fumigants like metam sodium (Martin, 2003) and 1, 3-

dichloropropene (1, 3-D) mixed with chloropicrin are less effective than methyl bromidechloropicrin mixes (Shaw and Larson, 1999; Yuen et al., 1991). Flat or broadcast fumigation with methyl bromide, chloropicrin or methyl bromide-chloropicrin mixes are the most effective methods of fumigation and have reduced soilborne fungi such as Macrophomina and Fusarium between 79-100\% (Martin, 2003). Due to increasing buffer zones and other regulations, growers are switching from flat fumigation to in-line fumigation under plastic beds. Inoculum can survive in furrows and bed shoulder areas if only the beds are fumigated (Matner, 2008). Biofumigants using isothiocyanates may also help to control Verticillium wilt and weeds (Matner, 2008; Gerald Holmes personal communication, 2016).

The efficacy of other available fumigants are limited resulting in the need for alternative pest control measures (Martin, 2003). Both chemical and non-chemical alternatives exist. For example, steam sterilization of soil and anaerobic soil disinfestation are alternatives to using chemical fumigants for certain pests and soil types, although the results are not always consistent (Shennan et al., 2012; Fennimore et al., 2012). Unless viable alternatives are found, the loss of methyl bromide will continue to have a severe impact on our nation's ability to meet the demands for strawberries. An integrated disease management approach is necessary for continued economically viable 
strawberry production in pathogen infested soils (Fennimore and Daugovish, 2012;

Koike, 2012).

\section{Soilborne Pathogens}

Macrophomina phaseolina $(\mathrm{Mp})$ and Fusarium oxysporum f. sp. fragariae $(\mathrm{Fof})$ are emerging soilborne strawberry pathogens that cause vascular wilting and chlorosis and necrosis of leaves, often leading to significant reduction in yield (Koike \& Gordon, 2015). $M p$ was first identified on strawberry in California (CA) in 2005 and is considered the most significant emerging soilborne threat to CA strawberry production because of its widespread distribution (Koike, 2012). Upon infection and plant death, $M p$ produces large numbers of microsclerotia, which are known to survive for many years in fallow fields. In other pathosystems, the survival of $M p$ in soil and on debris has been reported for up to 15 years (Baird et al., 2003). Fof was first confirmed in CA in 2006 and is considered the second most important soilborne threat to CA strawberry production (Koike et al., 2009). Fof is host specific to strawberry and survives in soil as chlamydospores for up to 15 years (Koike et al., 2009; Shennan et al., 2012).

$M p$ and Fof survive in infected crop debris and in soil as microsclerotia or chlamydospores, respectively. These survival structures serve as the primary source of inoculum in the subsequent strawberry crop in infested production fields and are resistant to desiccation and temperature extremes. Targeting the microsclerotia and chlamydospores of both strawberry pathogens in the soil will help in reducing primary inoculum and rate of secondary disease spread (Koike et al., 2013a; Leahy et al., 2013; Martin, 2003). 


\section{Macrophomina phaseolina}

Macrophomina phaseolina has been reported as the causal agent of charcoal rot of strawberrry in France (Baudry and Morzieres, 1993), Egypt (Maas, 1998), Florida

(Merteley et al., 2005), Isreal (Zveibil \& Freeman, 2005), Spain (Aviles et al., 2008) and Argentina (Baino et al., 2011). Mp was limited to the southern part of the CA (Ventura and Orange counties) in 2005; by 2010 charcoal rot cases were documented in Santa Cruz, Santa Clara, Alameda, and Sacramento counties (Koike et al., 2013a).

Macrophomina phaseolina is in the family Botryosphaeriaceae. It is a polyphagous fungus that appears in growing regions worldwide on a number of crops and has a wide host range of more than 500 plant families, including monocots and dicots (Gupta et al., 2012; Kaur et al., 2012; Zveibil et al., 2012; Smith and Carvil, 1977). Mp produces large numbers of melanized, multicellular structures referred to as microsclerotia (Gupta et al., 2012; Kaur et al., 2012; Koike and Bolda, 2013). Microsclerotia have been documented in living plant tissue as well as necrotic tissue. An individual microsclerotium is an aggregation of 50-200 individual cells that can germinate repeatedly coupled by a melanin pigment (Gupta et al., 2012; Kaur et al., 2012). They are black in color and range from 50 to $150 \mu \mathrm{m}$ in size (Gupta et al., 2012; Kaur et al., 2012). These microsclerotia are survival structures that allow the pathogen to persist in fallow fields (Kaur et al., 2012; Koike and Bolda, 2013), for up to fifteen years (Baird et al., 2003; Kaur et al., 2012). Olaya and Abawi (1996) documented the enhanced production of microsclerotia under low water potentials associated with drought; this is 
especially disconcerting given drought conditions over the past few production seasons on the central coast of CA.

Plants infected with $M p$ do not show symptoms initially, however, once the plant undergoes stress (e.g. starts to produce fruit), symptoms develop (Koike, 2012). Symptoms include discoloration of leaves, wilting, and overall plant decline and plant death (Gupta et al., 2012; Kaur et al., 2012; Koike, 2012; Koike and Bolda, 2013). Charcoal rot symptoms develop slowly in fall and winter, but increase rapidly during the spring and summer due to the warm soil temperature requirements of $M p$ (optimal range 25-30² ) (Mihail, 1992a; Wyllie et al., 1984; Zveibil et al., 2012). Fruit production is not affected by onset of symptoms until the plant starts to collapse from infection (Mertely et al., 2010; Mertely et al., 2014). Because symptoms of other soilborne and crown diseases look identical in the field, isolation from diseased tissue is required for proper diagnostics in strawberry (Koike, 2012; Koike and Bolda, 2013; Koike et al., 2013c; Zveibil et al., 2012).

\section{Fusarium oxysporum f. sp. fragariae}

Fusarium wilt of strawberries was first reported in Australia in 1962 (Winks and Williams, 1965) and Japan in 1969 (Okamoto et al., 1970) and subsequently Korea in 1982 (Kim et al., 1982), USA in 2006 (Koike et al., 2009), and China and Spain in 2009 (Koike and Gordon, 2015; Fang et al., 2012). Fusarium oxysporum f. sp. fragariae was first confirmed in CA in 2006 and is considered to be the second most important soilborne threat to CA strawberry production behind Macrophomina phaseolina (Koike and Gordon, 2015; Koike et al., 2009; Islas et al., 2011). Fof was initially limited to 
Ventura County, but has since been located throughout all production regions in California. (Islas et al., 2011).

Fusarium oxysporum is both a saprophyle and necrotroph and is commonly found in the fungal rhizosphere of many plants (Fang et al., 2012; Mihail, 1992b). Wilt inducing isolates of $F$. oxysporum are host-specific pathogens that have been divided into 120 different formae speciales (f.sp) (Fravel et al. 2003). Fof is host specific to strawberry

and its vascular tissue (Brayford, 1996; Fang et al., 2012; Koike et al., 2009). Fof hyphae invade the inter-cellular spaces of the epidermis, hypodermis and then move through the cell layer of the cortex to infect vascular tissue (Fang et al., 2012). Strawberry plants can show initial symptoms such as stunting, wilt, and decline as early as 30 days after transplanting (Koike and Gordon, 2015).

As plants exhibit symptoms of Fusarium wilt, internal vascular tissues of the crown and petiole often show a brownish orange discoloration (Koike and Gordon, 2015). Plating pieces of infected crown and petiole on a semi-selective medium is necessary to make a proper diagnosis (Koike et al., 2009; Koike and Gordon, 2015).

\section{Spread of the pathogens \& management of the diseases}

The movement of infested soil or plant material spreads both $M p$ and Fof (Brayford, 1996; Koike and Bolda, 2013; Koike and Gordon, 2015; Koike et al., 2013b \& c). Current management strategies involve the following: avoid planting in infested fields, rotate crops, apply pre-plant fumigants (methyl bromide plus chloropicrin flat fumigation is the most effective), grow cultivars that are tolerant to $M p$ or $F o f$, plant pathogen-free transplants, avoid planting into untreated buffer zones which may harbor soilborne 
inoculum, and avoid the movement of infested soil (Brayford, 1996; Koike et al., 2013; Koike and Bolda, 2013; Koike and Gordon, 2015; Gupta et al., 2012). Very limited studies have focused on the use of fungicides in controlling these diseases. Studies in Florida have shown inconsistent results in controlling $M p$ using different fungicides applied to soil (Mertely et al., 2010; Mertely et al., 2014). At this time, there have been no published studies demonstrating the use of fungicides in soil to manage Fof.

\section{Research Objectives}

The overall goal of this research is to develop and optimize different approaches for managing the emerging soilborne pathogens Macrophomina phaseolina $(\mathrm{Mp})$ and Fusarium oxysporum f. sp. fragariae (Fof) of strawberry. The specific objectives of my research include:

1. to evaluate the efficacy of various rates and the timing of soil-applied fungicides for managing Macrophomina crown rot and Fusarium wilt;

2. to examine the influence of whole strawberry plant extracts on the germination of $M p$ microsclerotia and explore their use as germination stimulants; and

3. to evaluate the combined use of strawberry plant extracts (obj. 2) with the most effective soil-applied fungicides (obj. 1) for managing Macrophomina crown rot. 


\title{
CHAPTER 2: EVALUATING THE EFFICACY OF VARIOUS RATES AND TIMING OF SOIL-APPLIED FUNGICIDES FOR MANAGING MACROPHOMINA CROWN ROT AND FUSARIUM WILT
}

\begin{abstract}
Macrophomina phaseolina (Mp) and Fusarium oxysporum f. sp. fragariae (Fof) are emerging soilborne pathogens causing crown rot and Fusarium wilt (respectively) in commercial strawberry production in California. Fungicides representing eight active ingredients from four different mode of action (FRAC) groups (1, 3, 7 and 12) were evaluated for their relative efficacy in controlling each pathogen in vitro and in planta. For the in vitro studies, active ingredients were evaluated for their ability to inhibit mycelial growth of both fungi. Half-strength potato dextrose agar was amended with six different concentrations $(0.01,0.1,1.0,5.0,10,50 \mu \mathrm{g}$ a.i./ml $)$ of seven active ingredients in FRAC groups 3, 7 and 12. Concentrations that inhibited fungal growth by $75 \%\left(\mathrm{EC}_{75}\right)$ compared to unamended media were determined for two different isolates each of $M p$ and Fof, and were then used to determine fungicide rates for in planta studies.

Tebuconazole strongly inhibited the mycelial growth of both pathogens (average $\mathrm{EC}_{75}$ for $M p$ was 2.4 ppm; average $\mathrm{EC}_{75}$ for $F$ of was $7.48 \mathrm{ppm}$ ), as did metconazole (average $\mathrm{EC}_{75}$ for $M p$ was 2.53 ppm; average $\mathrm{EC}_{75}$ for Fof was $1.28 \mathrm{ppm}$ ). Fludioxonil strongly inhibited mycelial growth of $M p$, but had no impact on the growth of Fof. Penthiopyrad, fluopyram, flutriafol, and flutolanil were less effective at inhibiting fungal growth of either fungus. Greenhouse in planta studies involved twenty-four fungicide treatments (eight fungicides at low, med and high rates) that were drench applied to infested potting media two days prior to planting of susceptible strawberry cultivars and twenty-one days
\end{abstract}


after planting. Buried inoculum was recovered at day two and 23 days after the first treatment application and plated on semi-selective media for colony forming unit (CFU) quantification. Plant disease assessments were made once a week for 11 weeks by calculating the area under the disease progress curve (AUDPC). An analysis of variance (ANOVA) of CFU counts of buried inoculum revealed no significant differences ( $\mathrm{p}>$ $0.05)$ among treatments for both $M p$ and $F o f$, but showed significant decreases $(\mathrm{p}<0.05)$ in CFU counts between one application (at week 1) and two applications (at weeks 1 and 3) for both $M p$ and Fof. An ANOVA of AUDPC showed significant decreases ( $<$ 0.001 ) in disease severity in treatments with penthiopyrad for $M p$ only (low, medium and high rates). There were no significant differences $(\mathrm{p}>0.05)$ in AUDPC between fungicide treatments and non-treated controls for Fof. This data indicates that these active ingredients did not provide effective control of these pathogens in planta.

\section{Introduction}

Currently, economically viable soilborne disease control alternatives to methyl bromide are lacking in commercial strawberry production. Strawberry producers will benefit from the development and optimization of novel ways to achieve soilborne disease control that can be integrated into existing conventional and organic production systems, or combined with other alternative approaches such as soil fungicides, anaerobic soil disinfestation (ASD), low rates of fumigants, or even steam.

Numerous fungicide chemistries have been utilized to manage soilborne crown and root diseases of other crops. The fungicides selected in this study were chosen due to success of pathogen control in other recent studies. Topguard ${ }^{\circledR}$ (flutriafol) was granted a 
section 18 exemption in 2012 for cotton farmers in TX and has been granted a supplemental label through 2018. Studies by Tom Isakeit at Texas A\&M have shown that one application of Topguard applied at planting demonstrated excellent potential as a fungicide for managing cotton root rot (Isakeit et al., 2011). Effectiveness of this product was associated with ample rain or overhead irrigation of cotton within one month of planting (Isakeit et al., 2011). However, there is more research that needs to be done to minimize the risk of phytotoxicity due to the long soil activity of this chemistry. In 2015, the US Environmental Protection Agency approved a supplemental flutriafol label in California for use on strawberries. The other five fungicides we selected to evaluate have been successfully used to control other soilborne diseases, and include Folicur (tebuconazole), Maxim (fludioxonil), Quash (metconazole), Fontelis (penthiopyrad), Moncut (flutolanil) and Topsin (thiophanate-methyl) (Ferry and Davis, 2012; Merteley et al. 2010; Merteley et al. 2014).

There is little information about fungicides currently used or evaluated for the management of $M p$ and Fof in strawberry. Florida studies showed that thiophanatemethyl has the ability to significantly reduce $M p$ disease incidence in raised-bed strawberries (Merteley et al. 2010; Merteley et al. 2014). These studies also showed that thiophanate-methyl and fluopyram were used together to increase fruit yield, but showed no significant difference in AUDPC caused by $M p$ (Merteley et al. 2014). There are no published studies pertaining to chemical control of Fof in strawberry at this point in time. Therefore, the goal of this research was to evaluate fungicides and to report their ability to manage both $M p$ and $F o f$. 


\section{Materials \& Methods}

\section{In vitro fungicide assays}

Two isolates of $M p$ (isolates 13 and 8), isolated from disease strawberry crowns from Irvine and Oxnard, CA, and two isolates of Fof (isolates 10.3 and 19), isolated from disease strawberry crowns from Santa Maria and Watsonville, CA, were used as test strains. The entire experiment was replicated twice. Trial I was conducted November 17, 2014 through January 6, 2015. Trial II was conducted December 2, 2014 through January 22, 2015. Seven fungicides from FRAC groups 3, 7 and 12 were selected for this experiment. Seven different concentrations $(0,0.01,0.1,1.0,5.0,10,50 \mathrm{ppm})$ of technical grade active ingredient were added to molten half-strength potato dextrose agar. A $5.5 \mathrm{~mm}^{2}$ plug of each actively growing $M p$ or Fof isolate was inverted (mycelium-side down) and placed in the center of each fungicide-amended and non-amended control plate; there were four replicates of each treatment combination for $M p$ and Fof. Radial mycelial growth was measured for $M p$ plates daily for the first two weeks and then twice per week through day 50. Radial mycelial growth was measured for Fof plates every other day through the third week and then twice per week through day 50 since Fof mycelium grows slower than $M p$. Mycelial plugs that showed no growth at day 50 were transferred to unamended half strength PDA and monitored for growth over the course of two weeks to assess the viability of the fungus since it did not grow during these assays.

Radial mycelial growth (mm per day) was converted to the area under the growth progress curve (AUGPC) to quantify isolate growth over the entire time frame of each experiment. The formula is as follows:

$$
\mathrm{AUGPC}=\sum_{i=1}^{n-1} \frac{y_{i}+y_{i+1}}{2} \times\left(t_{i+1}-t_{i}\right)
$$


Normalized growth rate of each treatment was regressed against the fungicide

concentration, which was used to calculate the concentrations that suppress fungal growth by $75 \%\left(\mathrm{EC}_{75}\right)$.

$$
\text { Normalized growth rate }=\frac{\text { AUGPC of treatment }}{\text { AUGPC of control }}
$$

Regression analyses were conducted using Minitab 16 Statistical Software (Minitab Inc., State College, PA).

\section{In planta Macrophomina study}

The same two isolates of $M p(M p 8$ and $M p 13)$ used in the in vitro experiments were grown on PDA and added to a cornmeal sand mixture to create inoculum (Mihail et al., 1992). Ten grams of inoculum was added to each trade one gallon pot (2.84 liter) with roughly $400 \mathrm{~g}$ potting media $\left[7 \mathrm{ft}^{3}\left(2.1 \mathrm{~m}^{3}\right)\right.$ peat moss, $7 \mathrm{ft}^{3}\left(2.1 \mathrm{~m}^{3}\right)$ coconut core, $7 \mathrm{ft}^{3}$ $\left(2.1 \mathrm{~m}^{3}\right)$ pearlite, $12 \mathrm{oz} .(340 \mathrm{~g})$ treble superphosphate, $18 \mathrm{oz} .(510 \mathrm{~g})$ potassium nitrate, 59 oz. $(1.67 \mathrm{~kg})$ dolomite lime and $1 \mathrm{oz} .(28 \mathrm{~g})$ micromax plus] to both the inoculated control and to each of twenty-four treatments (eight fungicides at low, med and high rates) (Table 2.1). Three grams of inoculum were buried in cotton mesh teabags about one inch $(25.4 \mathrm{~mm})$ below the soil surface in each pot. Treatment drenches occurred 2 days prior to planting of San Andreas plants and 21 days after initial drench $(450 \mathrm{ml}$ drench per pot as identified through preliminary unpublished studies). Each treatment consisted of six single-plant reps. Teabags with inoculum were recovered after each drench (reps 1, 3, 5 two days after; reps 2, 4, 6 twenty-three days after) and plated on RB media (Cloud and Rupe, 1991) from serial dilutions of $100 \mathrm{mg}$ inoculum/10 $\mathrm{ml}$ distilled 
water for CFU quantification (Lin et al., 2010; Mihail et al., 1992; Mihail and Alcorn, 1982).

Plant disease assessments were made every week starting two weeks after planting. Plants were rated on a scale of $1-5$; the rating of $1=$ no disease symptoms; $2=25 \%$ of plant wilted or necrotic; $3=50 \%$ of the plant wilted or necrotic; $4=75 \%$ of the plant wilted or necrotic; $5=$ dead plant (Figure 2.1). Scores were converted to percent disease $(1=0 \%, 2=25 \%, 3=50 \%, 4=75 \%$ and $5=100 \%)$; these percentages were then used to determine the area under the disease progress curve (AUDPC). The AUDPC equation is commonly used to quantify disease intensity over time in plant pathology. The AUDPC is a method that uses time variables (hours, days, weeks, months, or years) and calculates the average disease intensity that has accumulated between each pair of adjacent time points (Madden et al. 1990; Simko, 2012). The equation is as follows:

$$
A U D P C=\sum_{i=1}^{n-1} \frac{y_{i}+y_{i+1}}{2} \times\left(t_{i+1}-t_{i}\right)
$$

To determine if $M p$ was the cause of plant mortality, half of all strawberry crowns from plants that died during these assays were plated on acidified PDA (APDA). Trial I was conducted June 22 through September 11 of 2015 in greenhouse B at the Cal Poly Crops Unit. Trial II was conducted September 28 through December 18 of 2015 in an outside hoop house at the Cal Poly Crops Unit. 


\section{In planta Fusarium study}

The same two isolates of Fof (Fof 10.3 and 19) used in the in vitro experiments were grown on PDA for 21 days and added to sand to create inoculum according to the methods used by T. Gordon (Gordon et al., 2013). Approximately 70 grams of inoculum were added to approximately $400 \mathrm{~g}$ potting media to equal roughly 5,000 CFU/gram potting media. Teabags containing three grams of inoculum were buried in teabags one inch $(25.4 \mathrm{~mm})$ below soil surface. Drenches of 24 treatments (eight fungicides at low, med and high rates) (Table 2.1) and non-inoculated and inoculated controls occurred 2 days prior to planting of Monterey plants and 3 weeks after initial drench $(450 \mathrm{ml}$ drench per pot). Treatments consisted of five single-plant reps. Teabags of inoculum were recovered after each drench (reps 2 and 4 two days after; reps 1, 3, and 5 twenty three days after) and plated for quantification (Gordon et al., 2013). Plant disease assessments were made every week starting two weeks after planting as described in the above paragraph. Trial I was conducted December 2, 2015 through February 17, 2016. Trial II is currently being conducted. It began April 22 and will be completed July 8, 2016. Both trials have been conducted in greenhouse B at the Cal Poly Crops Unit.

\section{Statistical analysis}

A regression analysis using the normalized growth rate [area under the growth progress curve (AUGPC) quantitative summary] was used to generate an equation to determine effective concentrations (EC) of fungicides in vitro. An analysis of variance (ANOVA), was used to determine the significance of fungicide treatment effects on CFU counts. The GLM was used for both $M p$ and Fof bagged inoculum assays and AUDPC (plant disease 
assessments). Friedman's test and Tukey's method were used to determine median AUDPC rankings and groupings for $M p$. Dunnett's test was used to identify treatments significantly different than the inoculated control for Fof. Tukey's method was used to determine pairwise differences for Fof. The regression analysis and ANOVA were completed using Minitab 16 (Minitab Inc., State College, PA).

\section{Results}

\section{In vitro fungicide assays}

The data collected in both replicated in vitro trials consisted of radial mycelial growth measurements over time. Some of the treatments showed no measureable difference between the unamended control, while other treatments showed mycelial inhibition or little to no growth over time (Figure 2.2).

Mean fungicide concentrations that inhibited mycelial radial growth by $75 \%$ $\left(\mathrm{EC}_{75}\right)$ compared to unamended media over two trials were determined for two different isolates each of Mp and Fof (Table 2.2; see Appendix A.1 and Appendix A.2). Data was analyzed at day 34 and at day 50. Tebuconazole inhibited the mycelial growth of both $M p$ (the mean $\mathrm{EC}_{75}$ at day 34 for $M p$ isolate 13 was $2.98 \mu \mathrm{g} / \mathrm{ml}$ and $M p$ isolate 8 was 1.7 $\mu \mathrm{g} / \mathrm{ml}$; the mean $\mathrm{EC}_{75}$ at day 50 for $M p$ isolate 13 was $3.02 \mu \mathrm{g} / \mathrm{ml}$ and $M p$ isolate 8 was $1.71 \mu \mathrm{g} / \mathrm{ml}$ ) and $F o f\left(\right.$ mean $\mathrm{EC}_{75}$ at day 34 for $F$ of isolate 10.3 was $8.28 \mu \mathrm{g} / \mathrm{ml}$ and $F o f$ isolate 19 was $6.23 \mu \mathrm{g} / \mathrm{ml}$; the mean $\mathrm{EC}_{75}$ at day 50 for Fof isolate 10.3 was $9.26 \mu \mathrm{g} / \mathrm{ml}$ and Fof isolate 19 was $5.7 \mu \mathrm{g} / \mathrm{ml}$ ). Metconazole also inhibited mycelial growth of $M p$ (the mean $\mathrm{EC}_{75}$ at day 34 for $M p$ isolate 13 was $2.97 \mu \mathrm{g} / \mathrm{ml}$ and $M p$ isolate 8 was 2.14 $\mu \mathrm{g} / \mathrm{ml}$; the mean $\mathrm{EC}_{75}$ at day 50 for $M p$ isolate 13 was $2.9 \mu \mathrm{g} / \mathrm{ml}$ and $M p$ isolate 8 was 
$2.15 \mu \mathrm{g} / \mathrm{ml}$ ) and $F$ of (mean $\mathrm{EC}_{75}$ at day 34 for Fof isolate 10.3 was $1.11 \mu \mathrm{g} / \mathrm{ml}$ and $F o f$ isolate 19 was $1.4 \mu \mathrm{g} / \mathrm{ml}$; the mean $\mathrm{EC}_{75}$ at day 50 for $F$ of isolate 10.3 was $1.14 \mu \mathrm{g} / \mathrm{ml}$ and $F o f$ isolate 19 was $1.41 \mu \mathrm{g} / \mathrm{ml})$. Fludioxonil strongly inhibited mycelial growth of $M p$ (the mean $\mathrm{EC}_{75}$ at both day 34 and day 50 for $M p$ isolate 13 was $0.18 \mu \mathrm{g} / \mathrm{ml}$ and $M p$ isolate 8 was $0.15 \mu \mathrm{g} / \mathrm{ml}$ ), but had no impact on the mycelial growth of $F$ of ( $\mathrm{EC}_{75}$ values greater than 1,000 $\mu \mathrm{g} / \mathrm{ml}) . M p$ isolate 8 was more sensitive than $M p$ isolate 13 to the fungicide active ingredients. Penthiopyrad, fluopyram, flutriafol and flutolanil had $\mathrm{EC}_{75}$ values greater than $1,000 \mu \mathrm{g}$ a.i. $/ \mathrm{ml}$ and were considered less effective at inhibiting fungal growth of either fungus. Overall, $M p$ was more sensitive than $F o f$ to the active ingredients screened.

Mycelial plugs that did not show measureable growth on treatment plates (fludioxonil for $M p$ and metconazole for $F o f$ ) at day 50 were lifted and plated on unamended half strength PDA and monitored for growth over the course of two weeks to determine their viability after exposure to fungicide-amended media (Table 2.3). These plugs showed viability at 33\% and $44 \%$ for $M p 13$ and $M p 8$ respectively and $62.5 \%$ for both Fof 10.3 and Fof 19.

\section{In planta Macrophomina study}

The data collected in both replicated trials consisted of CFU counts of buried inoculum and plant disease assessments over time. There was a significant difference $(\mathrm{p}<0.05)$ between plating teabag inoculum after the first drench in week 1 (collected two days after first drench) and after the second drench in week 3 (collected 2 days after second drench) (Table 2.1, Table 2.4; see Appendix B.1) . Notably, there was a significant decrease of 
CFU counts between week 1 and week 3 for both trial I and trial II. In both trials there were no significant differences in CFU counts among week 1 treatments and no significant differences between any of the treatments and the untreated control $(\mathrm{p}>0.05)$. Both trials showed significant increases $(\mathrm{p}<0.05)$ of CFU/plate of some treatments as compared to the inoculated control at week 3. In trial I, flutriafol at a low rate and fludioxonil at the low and high rates showed higher CFU counts as compared to the untreated control. In trial II, metconazole at the high rate showed a significant increases $(\mathrm{p}<0.05)$ in the number of CFUs/plate compared to the untreated control.

Plant disease assessments (Figure 2.1) and corresponding AUDPC values did not meet the statistical requirements needed for a valid ANOVA for both $M p$ trials. Due to greenhouse temperatures (recorded in excess of $30^{\circ} \mathrm{C}$ in both soil and air) and pest pressure from powdery mildew (Podosphaera aphanis) and two spotted spider mite (Tetranychus urticae), disease assessments from the first trial of $M p$ were not used, as it was difficult to determine the cause of plant death/collapse. However, some plants were confirmed to have $M p$ through direct plating of crown tissue on APDA (Table 2.5). Less than $2 \%$ of all dead plant tissue from $M p$ trial I was positive for $M p$ while trial II resulted in roughly $12 \%$ of all dead plants being positive for the pathogen. However, I often waited too long to plate each plant after they died to get an accurate assessment for trial I.

The original AUDPC for $M p$ trial II data did not meet the statistical requirements for a valid ANOVA so a nonparametric analysis method, Friedman's test, of median AUDPC for each treatment was conducted instead (Figure 2.3, Table 2.1). The medians resulting from the Friedman's test were then used to perform an ANOVA and Tukey groupings with $90 \%$ simultaneous confidence intervals. There was a significant decrease $(\mathrm{p}<0.001)$ 
of median AUDPC with treatments containing the active ingredient penthiopyrad (treatments: J: low rate, K: med rate and L: high rate) (Figure 2.3, Table 2.1; see Appendix B.2) as compared to other treatments and to the inoculated control.

\section{In planta Fusarium study}

The data collected in both replicated Fof trials consisted of CFU counts of buried inoculum and plant disease assessments over time. There was a significant difference $(\mathrm{p}<$ 0.05) between CFU counts of buried inoculum after one drench in week 1 (collected 2 days after first drench) and after 2 drenches in week 3 (collected 2 days after second drench) (Table 2.1,Table 2.4). In trial I however, there were no significant differences (p $>0.05$ ) among treatments when compared to each other or the inoculated control (see Appendix B.1).

Plant disease assessments (Figure 2.1) were used to calculate AUDPC for trial I; AUDPC values did show significant differences $(\mathrm{p}<0.001)$ among treatments, but not when compared to the inoculated and non-inoculated control (Figure 2.4, Table 2.1; see Appendix B.2). Due to difficulties in producing inoculum at the required CFU counts needed for infection, a second trial of this study is in progress, but the data will not be included in this thesis.

\section{Discussion}

These results show that fungicides overall were ineffective at controlling the soilborne pathogens $M p$ and Fof in planta. In vitro trials showed that tebuconazole, metconazole, fludioxonil and, to a lesser extent, penthiopyrad were more effective at inhibiting 
mycelial growth of $M p$, while tebuconazole and metconazole were effective at inhibiting mycelial growth of Fof.

In planta greenhouse fungicide studies of $M p$ and Fof showed little to no control of both pathogens. Thiophanate-methyl was added to the study due to its ability to reduce disease incidence in raised-bed studies involving $M p$ of strawberries in Florida (Merteley et al. 2010; Merteley et al. 2014). These Florida studies also showed thiophanate-methyl and fluopyram were used together to increase fruit yield, but showed no significant difference in AUDPC (Merteley et al. 2014). The number of CFU counts per plate for both $M p$ and Fof were not significantly different from the control, showing that it is difficult to control these pathogens, in their resting state, using fungicides alone. An integrated approach will be needed to manage fields with existing inoculum and pathogen pressure.

The in planta data showed lower $M p$ disease incidence in treatments with penthiopyrad. Penthiopyrad also inhibited mycelial growth fairly well in the in vitro assays. Based on previous studies in Florida, thiophanate-methyl reduced disease severity in only one (2014) of the two field trials (Merteley et al. 2010). Our in planta pot trials showed no significant decrease in disease severity after thiophanate-methyl applications.

Due to the lack of research regarding chemical control of Fof, it was difficult to predict the outcome of the studies. These in vitro studies showed that many of the fungicide active ingredients that inhibited $M p$ were not as effective when used to treat $F o f$ inoculated plants. 


\section{Conclusion}

Of the chemical treatments evaluated in both in vitro and in planta studies, a limited number were effective at reducing radial mycelial growth, inoculum colony forming units and disease severity over time. In general, throughout the in planta studies, the number of colony forming units significantly decreased over time, but there were no significant differences among fungicide treatments and the control. Some of the fungicides tested reduced disease severity, but were not significant when compared to the control for both $M p$ and Fof. These studies show that tebuconazole and metconazole are effective at inhibiting mycelial growth for both pathogens in vitro, but not for controlling the disease in planta. 
Table 2.1. List of all in planta fungicide treatments.

\begin{tabular}{|c|c|}
\hline ID & Active Ingredient and Rate of Formulated Product \\
\hline A & Tebuconazole ${ }^{1}$-low rate $\left(1.52 \mathrm{ml} / 1.426\right.$ gal $\left.\mathrm{H}_{2} \mathrm{O}\right)$ \\
\hline B & Tebuconazole-med rate $\left(3.04 \mathrm{ml} / 1.426 \mathrm{gal}_{2} \mathrm{O}\right)$ \\
\hline $\mathrm{C}$ & Tebuconazole-high rate $\left(6.07 \mathrm{ml} / 1.426 \mathrm{gal} \mathrm{H}_{2} \mathrm{O}\right)$ \\
\hline $\mathrm{D}$ & Metconazole ${ }^{2}$-low rate $\left(0.81 \mathrm{~g} / 1.426 \mathrm{gal}_{2} \mathrm{O}\right)$ \\
\hline $\mathrm{E}$ & Metconazole-med rate $\left(1.62 \mathrm{~g} / 1.426 \mathrm{gal} \mathrm{H}_{2} \mathrm{O}\right)$ \\
\hline $\mathrm{F}$ & Metconazole-high rate $\left(2.43 \mathrm{~g} / 1.426 \mathrm{gal} \mathrm{H}_{2} \mathrm{O}\right)$ \\
\hline G & Flutriafol ${ }^{3}$-low rate $\left(3.41 \mathrm{ml} / 1.426 \mathrm{gal} \mathrm{H}_{2} \mathrm{O}\right)$ \\
\hline $\mathrm{H}$ & Flutriafol-med rate $\left(6.81 \mathrm{ml} / 1.426 \mathrm{gal}_{2} \mathrm{O}\right)$ \\
\hline I & Flutriafol-high rate $\left(13.63 \mathrm{ml} / 1.426 \mathrm{gal}_{2} \mathrm{O}\right)$ \\
\hline $\mathrm{J}$ & Penthiopyrad ${ }^{4}$-low rate $\left(5.06 \mathrm{ml} / 1.426\right.$ gal $\left._{2} \mathrm{O}\right)$ \\
\hline $\mathrm{K}$ & Penthiopyrad-med rate $\left(10.12 \mathrm{ml} / 1.426 \mathrm{gal}_{2} \mathrm{O}\right)$ \\
\hline $\mathrm{L}$ & Penthiopyrad-high rate $\left(20.24 \mathrm{ml} / 1.426 \mathrm{gal} \mathrm{H}_{2} \mathrm{O}\right)$ \\
\hline $\mathrm{M}$ & Fluopyram ${ }^{5}$-low rate $\left(1.44 \mathrm{ml} / 1.426 \mathrm{gal} \mathrm{H}_{2} \mathrm{O}\right)$ \\
\hline $\mathrm{N}$ & Fluopyram-med rate $\left(2.88 \mathrm{ml} / 1.426 \mathrm{gal}_{2} \mathrm{O}\right)$ \\
\hline $\mathrm{O}$ & Fluopyram-high rate $\left(5.77 \mathrm{ml} / 1.426 \mathrm{gal} \mathrm{H}_{2} \mathrm{O}\right)$ \\
\hline $\mathrm{P}$ & Flutolanil ${ }^{6}$-low rate $\left(2.3 \mathrm{~g} / 1.426 \mathrm{gal} \mathrm{H}_{2} \mathrm{O}\right)$ \\
\hline $\mathrm{Q}$ & Flutolanil-med rate $\left(4.59 \mathrm{~g} / 1.426 \mathrm{gal} \mathrm{H}_{2} \mathrm{O}\right)$ \\
\hline $\mathrm{R}$ & Flutolanil-high rate $\left(7.12 \mathrm{~g} / 1.426 \mathrm{gal} \mathrm{H}_{2} \mathrm{O}\right)$ \\
\hline $\mathrm{S}$ & Fludioxonil ${ }^{7}$-low rate $\left(1.41 \mathrm{~g} / 1.426 \mathrm{gal} \mathrm{H}_{2} \mathrm{O}\right)$ \\
\hline $\mathrm{T}$ & Fludioxonil-med rate $\left(2.83 \mathrm{~g} / 1.426 \mathrm{gal} \mathrm{H}_{2} \mathrm{O}\right)$ \\
\hline $\mathrm{U}$ & Fludioxonil-high rate $\left(5.66 \mathrm{~g} / 1.426 \mathrm{gal}_{2} \mathrm{O}\right)$ \\
\hline $\mathrm{V}$ & Thiophanate-methyl ${ }^{8}$-low rate $\left(4.22 \mathrm{ml} / 1.426\right.$ gal H$\left._{2} \mathrm{O}\right)$ \\
\hline $\mathrm{W}$ & Thiophanate-methyl-med rate $\left(8.43 \mathrm{ml} / 1.426 \mathrm{gal} \mathrm{H}_{2} \mathrm{O}\right)$ \\
\hline $\mathrm{X}$ & Thiophanate-methyl-high rate $\left(16.87 \mathrm{ml} / 1.426 \mathrm{gal} \mathrm{H}_{2} \mathrm{O}\right)$ \\
\hline $\mathrm{Y}$ & Inoculated control \\
\hline $\mathrm{Z}$ & Non-inoculated control \\
\hline \multicolumn{2}{|c|}{${ }^{1}$ Tebuconazole is the active ingredient in Tebuzole } \\
\hline \multicolumn{2}{|c|}{${ }^{2}$ Metconazole is the active ingredient in Ouash } \\
\hline \multicolumn{2}{|c|}{${ }^{3}$ Flutriafol is the active ingredient in Rhyme } \\
\hline \multicolumn{2}{|c|}{${ }^{4}$ Penthiopyrad is the active ingredient in Fontelis } \\
\hline \multicolumn{2}{|c|}{${ }^{5}$ Fluopyram is the active ingredient in Velum } \\
\hline \multicolumn{2}{|c|}{${ }^{6}$ Flutolanil is the active ingredient in Moncut } \\
\hline \multicolumn{2}{|c|}{${ }^{7}$ Fludioxonil is the active ingredient in Cannonball } \\
\hline${ }^{8}$ Thioph: & -methyl is the active ingredient in $\mathrm{To}$ \\
\hline
\end{tabular}



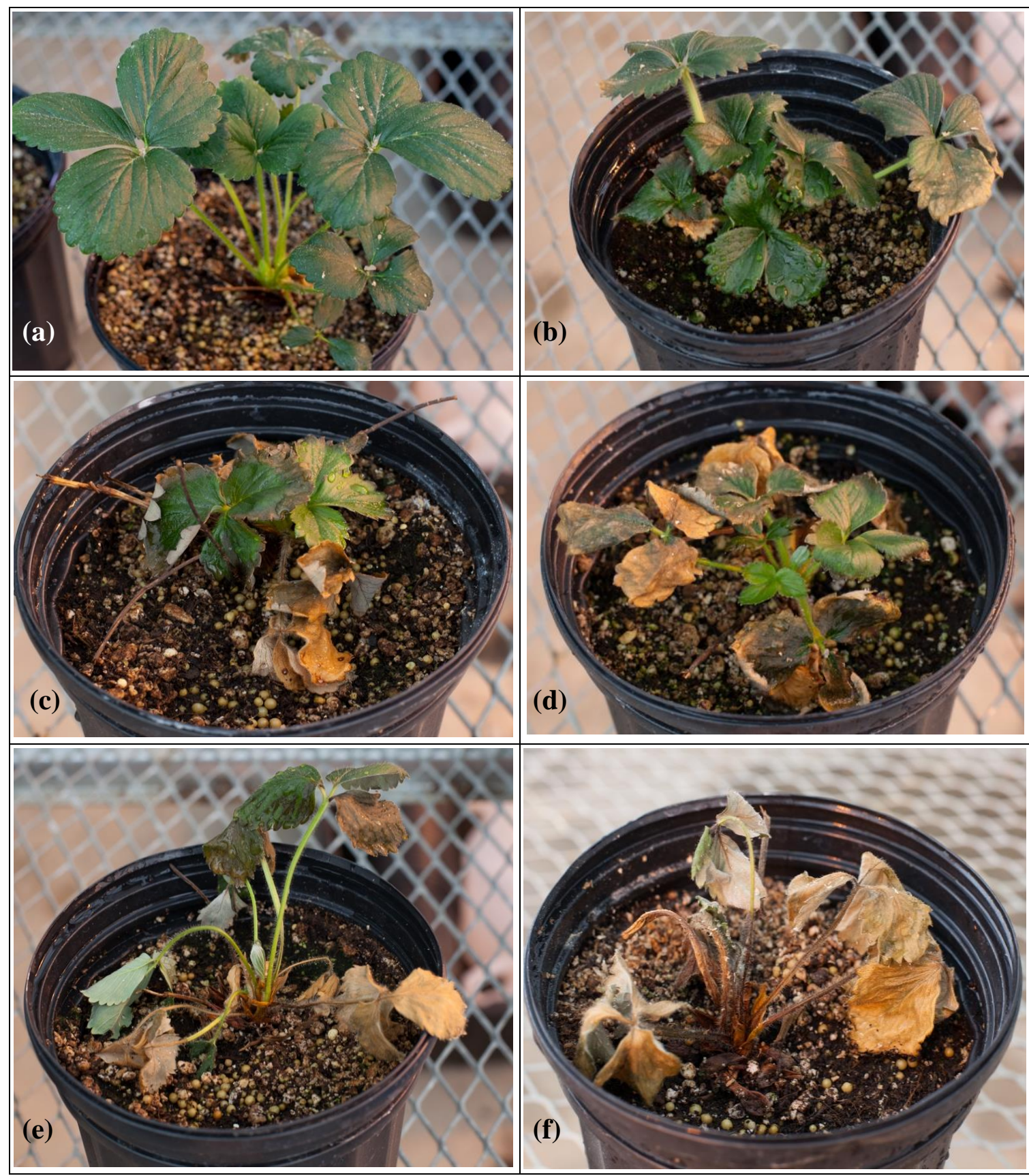

Figure 2.1. Rating scale guide: (a) no symptoms $=1$, (b) $25 \%$ wilt or necrosis $=2$, (c) $50 \%$ wilt and necrosis $=3$, (d) and (e) $75 \%$ wilt or necrosis $=4$ and (f) $100 \%$ wilt or necrosis $=5$. 


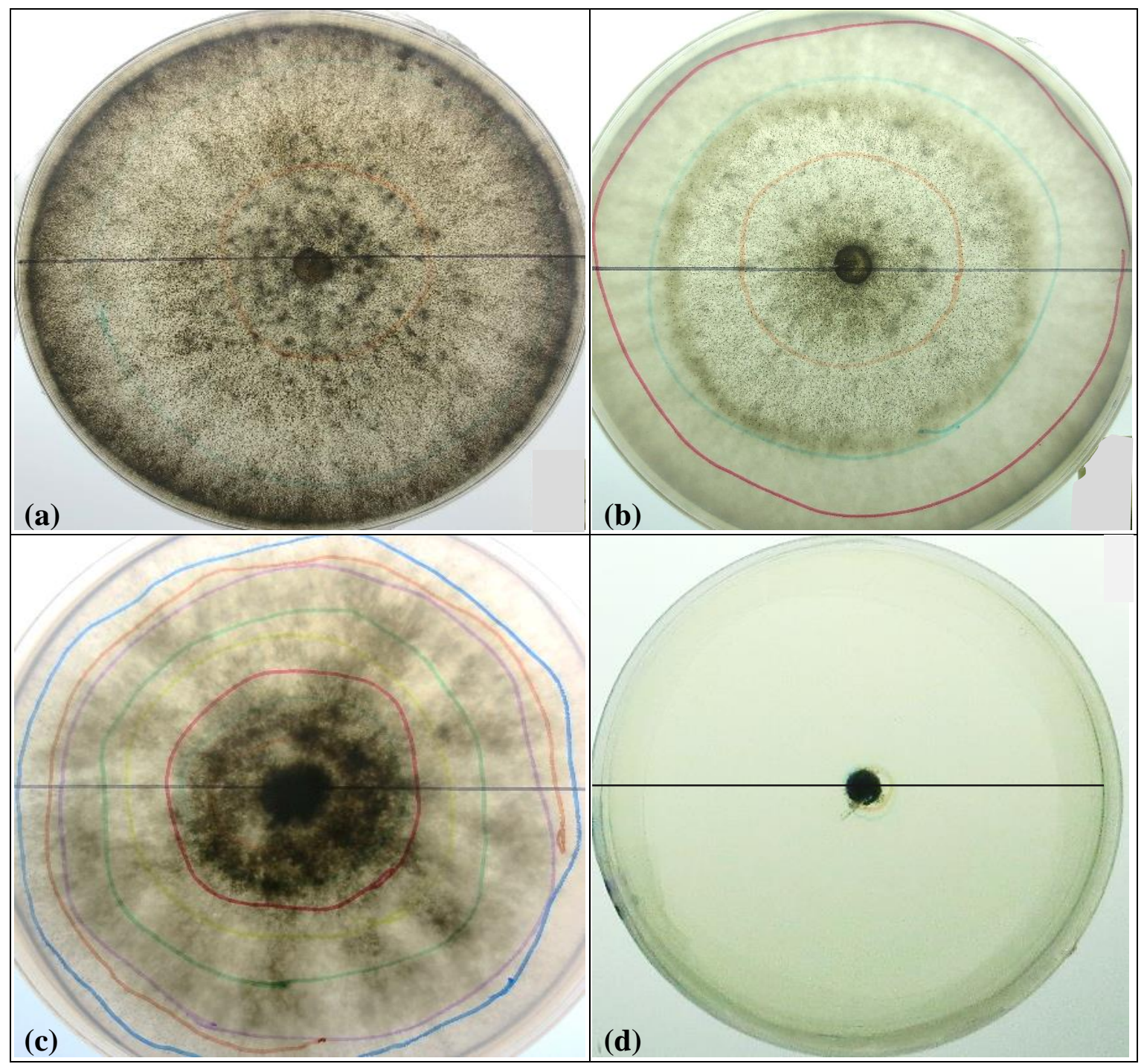

Figure 2.2. Mycelial growth of Macrophomina phaseolina on (a) unamended media (maximum colony diameter at day 4), (b) Flutriafol at $1 \mu \mathrm{g} / \mathrm{ml}$ (1 ppm) (maximum colony diameter at day 4), (c) Tebucaonazole at $1 \mu \mathrm{g} / \mathrm{ml}$ (1 ppm) (maximum colony diameter at day 15), and (d) Tebuconazole at $50 \mu \mathrm{g} / \mathrm{ml}$ (50 ppm) (minimal growth at day 50). 
Table 2.2. Mean concentrations of seven fungicides inhibiting mycelial radial growth by $75 \%$ (EC ${ }_{75}$ ) of Macrophomina phaseolina (Mp) and Fusarium oxysporum $\mathrm{f}$. sp. fragariae (Fof) in Petri dishes.

\begin{tabular}{|c|c|c|c|c|c|c|c|c|}
\hline & \multicolumn{4}{|c|}{$\begin{array}{c}\text { Average } \mathrm{EC}_{75} \boldsymbol{M} \boldsymbol{p}^{*} \\
(\mu \mathrm{g} / \mathrm{ml})\end{array}$} & \multicolumn{4}{|c|}{$\begin{array}{c}\text { Average } \mathrm{EC}_{75} \boldsymbol{F o f}^{*} \\
(\mu \mathrm{g} / \mathrm{ml})\end{array}$} \\
\hline & \multicolumn{2}{|c|}{ Day 34} & \multicolumn{2}{|c|}{ Day 50} & \multicolumn{2}{|c|}{ Day 34} & \multicolumn{2}{|c|}{ Day 50} \\
\hline & \multicolumn{2}{|c|}{ Isolate ID } & \multicolumn{2}{|c|}{ Isolate ID } & \multicolumn{2}{|c|}{ Isolate ID } & \multicolumn{2}{|c|}{ Isolate ID } \\
\hline Ingredient & Mp 13 & $M p 8$ & Mp 13 & $M p 8$ & Fof 10.3 & Fof 19 & Fof 10.3 & Fof 19 \\
\hline Tebuconazole & 2.98 & $1.70 * *$ & 3.02 & $1.71 * *$ & 8.28 & 6.23 & 9.26 & 5.7 \\
\hline Metconazole & 2.97 & 2.14 & 2.9 & 2.15 & 1.11 & 1.4 & 1.14 & 1.41 \\
\hline Flutriafol & $47.17^{* *}$ & 55.96 & 50.77 & 55.96 & 301.44 & $460.36^{* *}$ & 262.3 & $310.38 * *$ \\
\hline Penthiopyrad & 5.83 & 5.12 & 5.83 & 5.1 & $>* * *$ & $>$ & $>* * *$ & $>$ \\
\hline Fluopyram & $9.24 * *$ & 22.24 & $9.24 * *$ & 22.24 & $>* * *$ & $>* *$ & $>* * *$ & $>* *$ \\
\hline Flutolanil & $221.23 * * *$ & $150.05^{* * *}$ & $200.13^{* * *}$ & $150.05^{* * *}$ & $>* * *$ & $>* * *$ & $>* * *$ & $>* * *$ \\
\hline Fludioxonil & $0.18^{* *}$ & $0.15^{* * *}$ & $0.18 * *$ & $0.15^{* * *}$ & $>* * *$ & $>* * *$ & $>* * *$ & $>* * *$ \\
\hline
\end{tabular}


Table 2.3. Percent viable plugs ${ }^{\mathrm{a}}$ after exposure to active ingredients at day 50 .

\begin{tabular}{|c|c|c|c|c|c|}
\hline \multirow[b]{2}{*}{ Active Ingredient } & \multirow[b]{2}{*}{ Rate } & \multicolumn{4}{|c|}{ Isolate ID } \\
\hline & & Mp 13 & $M p 8$ & Fof 10.3 & Fof 19 \\
\hline \multirow[t]{4}{*}{ Fludioxonil } & $1 \mu \mathrm{g} / \mathrm{ml}$ & $100 \%(1)^{\mathrm{b}}$ & $50 \%(2)$ & & \\
\hline & $5 \mu \mathrm{g} / \mathrm{ml}$ & $0 \%$ & & & \\
\hline & $10 \mu \mathrm{g} / \mathrm{ml}$ & $0 \%(3)$ & $33 \%(3)$ & & \\
\hline & $50 \mu \mathrm{g} / \mathrm{ml}$ & $50 \%(4)$ & $50 \%(4)$ & & \\
\hline \multirow[t]{2}{*}{ Metconazole } & $10 \mu \mathrm{g} / \mathrm{ml}$ & & & $100 \%(4)$ & $100 \%(4)$ \\
\hline & $50 \mu \mathrm{g} / \mathrm{ml}$ & & & $25 \%(4)$ & $25 \%(4)$ \\
\hline
\end{tabular}

a Plugs from fungicide-amended media (in vitro study) that did not have measurable growth at day 50 were transferred to new half-strength PDA plates without active ingredients. Plugs were monitored for growth over 14 days.

${ }^{\mathrm{b}}$ Number in parentheses indicates number of plugs plated. 
Table 2.4. Mean Colony Forming Units (CFUs) per plate of inoculum that was buried in bags and received fungicide treatments.

\begin{tabular}{|c|c|c|c|c|c|c|c|c|c|}
\hline \multirow[b]{3}{*}{ Treatment ${ }^{\mathrm{a}}$} & & \multicolumn{4}{|c|}{ Trial I } & \multicolumn{4}{|c|}{ Trial II } \\
\hline & & \multicolumn{2}{|c|}{ Macrophomina phaseolina } & \multicolumn{2}{|c|}{$\begin{array}{l}\text { Fusarium oxysporum f. sp. } \\
\text { fragariae }\end{array}$} & \multicolumn{2}{|c|}{ Macrophomina phaseolina } & \multicolumn{2}{|c|}{$\begin{array}{l}\text { Fusarium oxysporum f. sp. } \\
\text { fragariae }\end{array}$} \\
\hline & & week 1 & week 3 & week 1 & week 3 & week 1 & week 3 & week 1 & week 3 \\
\hline \multirow{3}{*}{ Tebuconazole } & A & 112.67 & 8.25 & 3.75 & 3 & 117.33 & 12.67 & - & - \\
\hline & B & 100.33 & 10.25 & 3 & 1.17 & 64.67 & 14.33 & - & - \\
\hline & $\mathrm{C}$ & 124.83 & 4.75 & 6 & 1.17 & 75.33 & 29.83 & - & - \\
\hline \multirow{3}{*}{ Metconazole } & $\mathrm{D}$ & 83 & 7.25 & NA & 1.67 & 122 & 18 & - & - \\
\hline & $\mathrm{E}$ & 154.5 & 15.25 & 7.5 & 0.67 & 89.33 & 3.5 & - & - \\
\hline & $\mathrm{F}$ & 127.83 & 5.5 & 2.75 & 1.67 & 122.67 & $59.5^{*}$ & - & - \\
\hline \multirow{3}{*}{ Flutriafol } & $\mathrm{G}$ & 97 & $24.75^{*}$ & 3.5 & 0.17 & 84.83 & 19.83 & - & - \\
\hline & $\mathrm{H}$ & 106.17 & 9.5 & 5.5 & 0.17 & 101.5 & 12.5 & - & - \\
\hline & I & 90.75 & 7.75 & 3 & 0.5 & 81 & 19.67 & - & - \\
\hline \multirow{3}{*}{ Penthiopyrad } & $\mathrm{J}$ & 153.17 & 10.25 & 13 & 0.5 & 84.83 & 3 & - & - \\
\hline & $\mathrm{K}$ & 162.83 & 8.75 & 6 & 1.17 & 141.83 & 3.17 & - & - \\
\hline & $\mathrm{L}$ & 133.17 & 5 & 9 & 0.17 & 112 & 1.83 & - & - \\
\hline \multirow{3}{*}{ Fluopyram } & $\mathrm{M}$ & 96.33 & 9 & 4 & 1 & 139.17 & 10.33 & - & - \\
\hline & $\mathrm{N}$ & 121.83 & 4.75 & 8.25 & 1.33 & 124.17 & 5.33 & - & - \\
\hline & $\mathrm{O}$ & 153.17 & 4.25 & 6 & 0.5 & 98.5 & 3.67 & - & - \\
\hline \multirow{3}{*}{ Flutolanil } & $\mathrm{P}$ & 95.33 & 15.25 & 4.75 & 1.33 & 94 & 11.17 & - & - \\
\hline & Q & 187.83 & 9.75 & 7.5 & 0.5 & 103.83 & 9.5 & - & - \\
\hline & $\mathrm{R}$ & 104.5 & 13.25 & 2.75 & 2.33 & 102 & 9.67 & - & - \\
\hline \multirow{3}{*}{ Fludioxonil } & $S$ & 138 & $31.50 *$ & 10.5 & 0.67 & 126.5 & 8.83 & - & - \\
\hline & $\mathrm{T}$ & 181.5 & 11.5 & 5 & 0.67 & 117.5 & 12.17 & - & - \\
\hline & U & 186.33 & $38.75^{*}$ & 8 & 0.33 & 130.5 & 32.33 & - & - \\
\hline \multirow{3}{*}{$\begin{array}{r}\text { Thiophanate- } \\
\text { Methyl }\end{array}$} & $\mathrm{V}$ & 75.83 & 5.75 & 3 & 0 & 132.83 & 6.33 & - & - \\
\hline & W & 84.33 & 8.25 & 6.5 & 0.5 & 102.33 & 9 & - & - \\
\hline & $X$ & 54.67 & 7 & 1.5 & 0.33 & 95.33 & 21 & - & - \\
\hline Inoculated Cont & trol & 189 & 11.5 & 7.25 & 1 & 108.83 & 13.33 & - & - \\
\hline
\end{tabular}

a Treatment ID- see table 2.1 for descriptions of each treatment.

* Significantly higher than inoculated control.

CFUs counted on media: RB for $M p$ (6 reps of each treatment) \& Komada for Fof ( 5 reps of each treatment) for two trials in planta.

See Appendix B.1 for data analysis. 
Table 2.5. Number of dead plants confirmed with $M p$ or $F$ of by direct plating after fungicide treatment.

\begin{tabular}{|c|c|c|c|c|c|}
\hline \multirow[b]{3}{*}{ Treatment } & & \multicolumn{4}{|c|}{ Pathogen } \\
\hline & & \multicolumn{2}{|c|}{ Macrophomina phaseolina ${ }^{a}$} & \multicolumn{2}{|c|}{$\begin{array}{l}\text { Fusarium oxysporum f. sp. } \\
\text { fragariae }\end{array}$} \\
\hline & & Trial I & Trial II & Trial I & Trial $\mathrm{II}^{\mathrm{b}}$ \\
\hline \multirow{3}{*}{ Tebuconazole } & A & $0(4)^{c}$ & $0(1)$ & $75 \%(4)$ & - \\
\hline & $\mathrm{B}$ & $0(4)$ & $0(1)$ & $40 \%(5)$ & - \\
\hline & $\mathrm{C}$ & $0(6)$ & $0(4)$ & $40 \%(5)$ & - \\
\hline \multirow{3}{*}{ Metconazole } & $\mathrm{D}$ & $0(5)$ & $0(2)$ & $0(5)$ & - \\
\hline & $\mathrm{E}$ & $0(6)$ & $33 \%(3)$ & $60 \%(5)$ & - \\
\hline & $\mathrm{F}$ & $0(6)$ & $0(3)$ & $20 \%(5)$ & - \\
\hline \multirow{3}{*}{ Flutriafol } & $\mathrm{G}$ & $0(6)$ & $0(6)$ & $40 \%(5)$ & - \\
\hline & $\mathrm{H}$ & $0(6)$ & $0(6)$ & $0(5)$ & - \\
\hline & $\mathrm{I}$ & $0(6)$ & $0(6)$ & $40 \%(5)$ & - \\
\hline \multirow{3}{*}{ Penthiopyrad } & $\mathrm{J}$ & $0(5)$ & $\mathrm{NA}^{\mathrm{d}}$ & $0(2)$ & - \\
\hline & $\mathrm{K}$ & $0(6)$ & NA & NA & - \\
\hline & $\mathrm{L}$ & $0(3)$ & NA & NA & - \\
\hline \multirow{3}{*}{ Fluopyram } & M & $0(4)$ & $0(1)$ & $0(2)$ & - \\
\hline & $\mathrm{N}$ & $0(6)$ & $0(3)$ & $0(2)$ & - \\
\hline & $\mathrm{O}$ & $0(3)$ & $0(1)$ & $0(2)$ & - \\
\hline \multirow{3}{*}{ Flutolanil } & $\mathrm{P}$ & $0(6)$ & $66 \%(3)$ & $0(4)$ & - \\
\hline & $\mathrm{Q}$ & $16 \%(6)$ & $40 \%(5)$ & $66 \%(3)$ & - \\
\hline & $\mathrm{R}$ & $0(6)$ & $33 \%(3)$ & $20 \%(5)$ & - \\
\hline \multirow{3}{*}{ Fludioxonil } & $\mathrm{S}$ & $0(6)$ & NA & $0(4)$ & - \\
\hline & $\mathrm{T}$ & $0(6)$ & $0(1)$ & $0(3)$ & - \\
\hline & $\mathrm{U}$ & $0(6)$ & $0(3)$ & $75 \%(4)$ & - \\
\hline \multirow{3}{*}{$\begin{array}{l}\text { Thiophanate- } \\
\text { methyl }\end{array}$} & $\mathrm{V}$ & $0(6)$ & $25 \%(4)$ & $50 \%(2)$ & - \\
\hline & $\mathrm{W}$ & $0(6)$ & NA & NA & - \\
\hline & $X$ & $0(5)$ & $0(2)$ & $50 \%(2)$ & - \\
\hline \multirow{2}{*}{$\begin{array}{l}\text { Inoculated } \\
\text { control } \\
\text { Non-inoculated } \\
\text { control }\end{array}$} & $\mathrm{Y}$ & $33 \%(6)$ & $60 \%(5)$ & $50 \%(2)$ & - \\
\hline & $\mathrm{Z}$ & $0(5)$ & $0(1)$ & $0(2)$ & - \\
\hline
\end{tabular}

${ }^{\mathrm{a}}$ Half of all dead plants per treatment were plated on acidified potato dextrose agar for the detection of $M p$ or Fof.

$\mathrm{b}$ Trial currently taking place.

${ }^{\mathrm{c}}$ Number in parentheses is the total number of crowns plated.

${ }^{\mathrm{d}}$ NA None of the plants in these treatments died. 


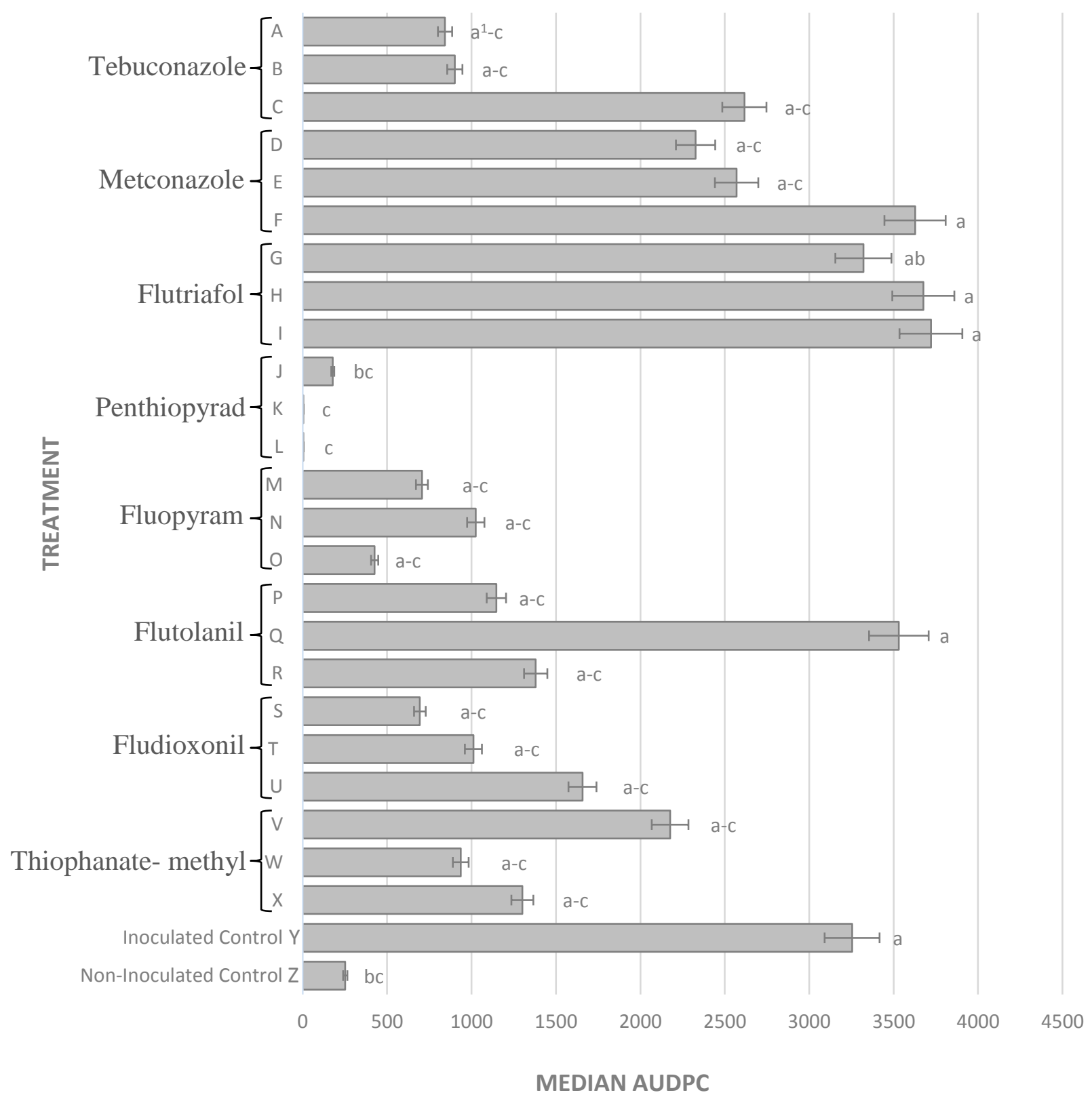

Figure 2.3. Median AUDPC for Macrophomina phaseolina in planta fungicide trial II.

${ }^{1}$ Tukey grouping in block ranked AUDPC median and 90\% simultaneous confidence intervals. Means that do not share the same letter are significantly different. Groupings based on six reps of each treatment.

See Appendix B.2 for data analysis. 


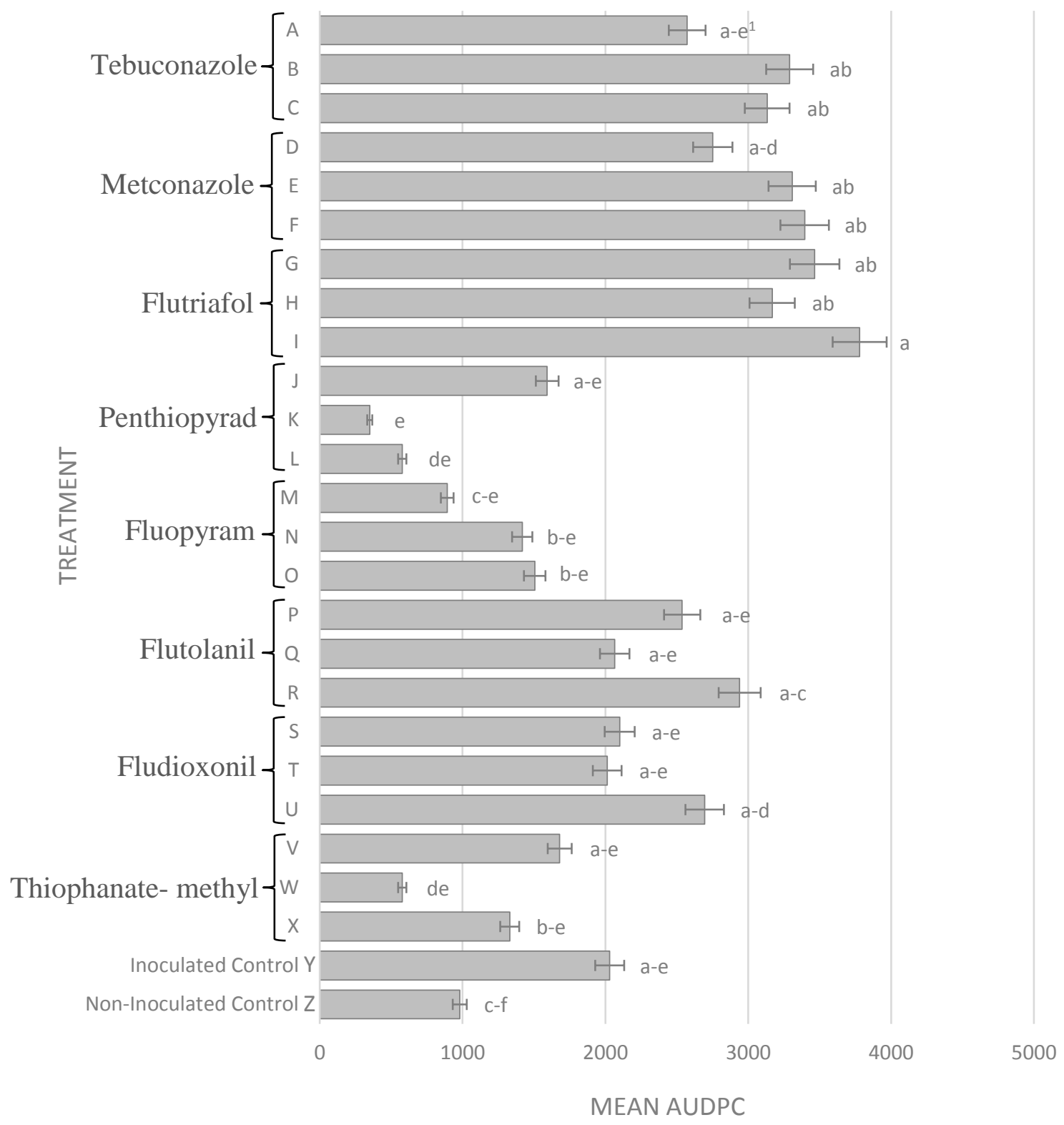

Figure 2.4. Mean AUDPC for Fusarium oxysporum f. sp. fragariae in planta fungicide trial I.

${ }^{1}$ Tukey grouping based on $90 \%$ simultaneous confidence intervals. Means that do not share the same letter are significantly different. Groupings based on six reps of each treatment.

See Appendix B.2 for data analysis. 


\title{
CHAPTER 3: EXAMINING THE INFLUENCE OF STRAWBERRY PLANT EXTRACTS ON GERMINATION OF MACROPHOMINA PHASEOLINA MICROSCLEROTIA
}

\begin{abstract}
Macrophomina phaseolina $(\mathrm{Mp})$ is an emerging soilborne pathogen causing crown rot in commercial strawberry fields in California. A strawberry whole plant extract was assessed for its ability to stimulate the germination of $M p$ microsclerotia in vitro and in planta. For the in vitro trials, the plant extract was applied as a drench at six different concentrations $(0,10,100,1,000,10,000$ and $30,000 \mathrm{ppm})$ at day 0 and day 14 in Petri dishes containing filter packets of $M p$ microsclerotia. Filter packets were retrieved 3 days after the drench and processed by microscopy to determine the number of germinated microsclerotia. Results showed that the number of germinated microsclerotia was significantly higher $(\mathrm{p}<0.001)$ after the application of the strawberry plant extracts compared to non-drench and water $(0 \mathrm{ppm})$ controls. An in planta container trial was also conducted using a strawberry extract at $10,000 \mathrm{ppm}$ applied 3 days prior to a fungicide drench (tebuconazole or thiophanate-methyl) to assess the effect of fungicides on germinated microsclerotia. The use of strawberry plant extracts as germination stimulants with label rates of both fungicides lowered the number of living germinated microsclerotia significantly $(\mathrm{p}<0.001)$, especially after two drench applications of the strawberry plant extract and fungicide combinations. In the future, field trials will be necessary to determine if strawberry plant extracts could be coupled with fungicides as a potential control measure for Macrophomina crown rot of strawberry.
\end{abstract}




\section{Introduction}

A novel approach targeting sclerotia of Sclerotium cepivorum has been developed which shows potential as an integrated control measure for managing white rot of garlic and onion in central California (Coventry et al., 2002; Davis et al., 2007; Hovius and McDonald, 2002). This method involves the application of host plant extracts (i.e. onion and garlic extractions) to white rot infested fields in the absence of a crop in order to "trick" or stimulate pathogen sclerotia to germinate. These host plant extracts are commonly referred to as germination stimulants. Numerous studies involving this approach in garlic production have reported white rot control similar to results achieved with methyl bromide (Hovius and McDonald, 2002).

Garlic and onion bulbs and roots continuously leak exudates at low levels naturally, which induce germination of sclerotia produced by S. cepivorum at very high rates (Hovius and McDonald, 2002). One such stimulatory substance isolated from onion and garlic is diallyl disulfide, often referred to as DADS (Crowe et al., 1993). When DADS was applied by injection or irrigation throughout field soil in the absence of an actual onion crop, 90-99\% of the pathogen sclerotia germinated (Coley-Smith and Parfitt, 1986). Numerous studies involving DADS, as well as food grade garlic powder, garlic juice, and garlic bulb exudates have shown similar results. Control of garlic white rot was similar to control achieved with methyl bromide (Davis et al., 2007; Hovius and McDonald, 2002). Field trials conducted in Kern and San Benito Counties in California garlic fields reported over $90 \%$ death of sclerotia of S. cepivorum within 3 months after application of these germination stimulants (Davis et al., 2007;). 
There are limitations regarding the use of germination stimulants for controlling white rot of garlic in California; these products cannot be applied when the host crop is growing in the field and further studies showed that the best control of white rot was achieved when fields lay fallow for 3-6 months after treatment. Additional studies determined that this method is most effective when combined with soil-applied fungicides (Ferry and Davis, 2012). None of the five fungicides tested by Ferry and Davis significantly reduced white rot when applied alone. However, when combined as a treatment one week after the application of DADS, all fungicides significantly reduced disease severity without requiring a fallow period. This technique could be utilized by strawberry producers as a pre-plant treatment in fallow fields before the application of soil fungicides, ASD, low rates of fumigants, or even steam as an integrated program for managing soilborne pathogens. It is widely documented that sclerotia are more tolerant of extreme conditions and that the vegetative mycelium of fungi is much more sensitive to treatments such as fumigants, fungicides, and temperature extremes (Davis et al., 2007; Hovius and McDonald, 2002).

The objectives of this study were 1) to evaluate the use of strawberry whole plant extracts as potential microsclerotia germination stimulants for $M p$, and 2) to evaluate the combined use of strawberry plant extracts with the most effective soil-applied fungicides for managing Macrophomina crown rot. 


\section{Materials \& Methods}

\section{Strawberry plant extract production}

Twenty pounds of mature Albion strawberry plants were collected from a production field. The plants were washed free of soil, and fruit and necrotic tissue were removed. Leaf, stem, crown and root tissue was finely chopped using a 14-cup Cuisinart food processor (Cuisinart, E Windsor, New Jersey). Strawberry plant material was added to sterilized deionized water to achieve a 7:3 (700 ml distilled water: 300 g plant material) volume-to-volume ratio. Enzymes from California Safe Soil were added per $500 \mathrm{~g}$ strawberry plant material as follows: Enzyme A at $0.5 \mathrm{ml}$, enzyme B at $3 \mu \mathrm{l}$ and enzyme $\mathrm{C}$ at $1.2 \mathrm{~g}$. In order to activate enzymes, the solution was placed in glass jars and submerged in a water bath at $55^{\circ} \mathrm{C}$ under constant agitation for 3.5 hours. The heat was then increased to $77^{\circ} \mathrm{C}$ for 30 minutes under constant agitation in order to deactivate the enzymes. This solution was stored in the refrigerator for up to four weeks. The resulting slurry was passed through sterile cheesecloth to remove solids, and only the filtrate was used. The initial concentration (stock) of the germination stimulant was 300,000 ppm. All concentrations were made using this stock and diluted using sterile deionized water.

\section{Macrophomina phaseolina microsclerotia packets}

Three isolates of $M p(M p 8, M p 13$ and $M p$ 20; isolated from diseased strawberry crowns from Irvine and Oxnard, CA) were grown on wooden toothpicks (Mihail, 1992) for two weeks then air dried and stored in the dark at room temperature. Microsclerotia were transferred to filter disks (Fisherbrand ${ }^{\circledR}$ filter \#20, $86 \mathrm{~mm}$ diameter) by scraping them off 
the toothpicks. Filter disks were folded and glued shut using Elmer's Glue. These microsclerotia packets were used in both in vitro and in planta studies.

\section{In vitro germination trials}

This in vitro study was repeated twice. Trial I was conducted February 19, 2016 through March 7, 2016 and trial II was conducted March 11, 2016 through March 28, 2016. A clay-loam soil from a pre-plant fumigated strawberry field was sterilized by autoclaving twice for 60 minutes, amended with vermiculite (80:20, soil: vermiculite, volume to volume) to prevent aggregate blocking and improve water mobility. Two tablespoons of this soil mix was added to each deep $86 \mathrm{~mm}$ diameter Petri dish. One microsclerotia packet was added and then covered with another tablespoon of soil mix. On day $0,10 \mathrm{ml}$ of five concentrations of the germination stimulant $(0,10,100,1,000,10,000$ and 30,000 ppm) were applied evenly to the soil. There were four controls: no drench and no microsclerotia packet, no drench with a microsclerotia packet, 30,000 ppm germination stimulant with no microsclerotia packet, and sterile distilled water only with microsclerotia packet. Petri dishes were then stored in the dark. Each treatment and drench combination had six replicates.

On day 3 , one set of the six replicates of each treatment was evaluated. Microsclerotia packets were removed from the soil and placed on standard glass slides to quantify the number of germinated microsclerotia. Each slide was treated with a $2 \%$ lactophenol blue and distilled water then covered with a glass cover slip. Slides were evaluated under the compound microscope at $20 \mathrm{X}$ magnification to visualize 
microsclerotia. The number of germinated and non-germinated microsclerotia were counted in the area of one cover slip $\left(22 \mathrm{~mm}^{2}\right)$.

A second drench of each treatment was applied to one set of the six replicate dishes on day 14. On day 17, microsclerotia packets were removed from the set of six replicate dishes that received the second drench, as well as the remaining set of six replicate dishes that only received the first drench on day 0 . The microsclerotia packets were prepared and analyzed as described in the above paragraph.

\section{In planta germination trials}

This experiment was designed to assess differences in the number of plant extract drenches (one or two) for their ability to induce the germination of $M p$ microsclerotia. This experiment was only conducted once (from March 1, 206 through June 11, 2016) due to time limitations and is still in progress (Table 3.1).

The same three isolates of $M p$ used in the in vitro experiments were also used in these in planta trials. Isolates were grown on potato dextrose agar (PDA) and then added to a cornmeal sand mixture to create inoculum (Mihail et al., 1992b). Inoculum was incubated for two weeks at $30^{\circ} \mathrm{C}$. Ten grams of inoculum was added to each one gallon pot (2.84 liter) with roughly $400 \mathrm{~g}$ potting media $\left[7 \mathrm{ft}^{3}\left(2.1 \mathrm{~m}^{3}\right)\right.$ peat moss, $7 \mathrm{ft}^{3}\left(2.1 \mathrm{~m}^{3}\right)$ coconut core, $7 \mathrm{ft}^{3}\left(2.1 \mathrm{~m}^{3}\right)$ pearlite, $12 \mathrm{oz} .(340 \mathrm{~g})$ treble superphosphate, $18 \mathrm{oz} .(510 \mathrm{~g})$ potassium nitrate, $59 \mathrm{oz} .(1.67 \mathrm{~kg})$ dolomite lime and $1 \mathrm{oz} .(28 \mathrm{~g})$ micromax plus] for inoculated controls ( 0 ppm plant extract and no drench) and to all treatment pots receiving the five different concentrations of the plant extract $(0,10,100,1,000,10,000$ and 30,000 ppm). Microsclerotia packets were placed in cotton mesh teabags that were 
buried approximately $25.4 \mathrm{~mm}$ below soil surface in each pot. Drenches of treatments and non-inoculated and inoculated controls occurred two days prior to the planting of cultivar San Andreas transplants and two weeks after initial drench $(450 \mathrm{ml}$ drench per pot at day 0). Treatments consisted of six single-plant replications; there were two sets of replications. The first replicate set of pots contained two individual teabags with a microsclerotia packet; the second set of replicate pots contained only one teabag with a microsclerotia packet. Bare root plants were planted in the first set of replicates on day 14 and assessed starting day 28 (two weeks after planting) by rating plants for disease symptoms (Figure 2.1). Bare root plants were planted two weeks after the second drench treatment in the second set of replicates (day 28) and disease assessments started two weeks (day 42) after planting date (Table 3.1).

One teabag containing the microsclerotia packet was recovered on day three after the first drench of plant extract and mounted on slides as described above. A second drench of the plant extract was applied to the pots on day 14. Three days after this extract drench on day 17 , the second teabag containing the microsclerotia packet from the first replicate set the only teabag from the second replicate set was recovered. The microsclerotia packet was mounted on slides as described above and microsclerotia were assessed for germination (Table 3.1).

Plant disease assessments were made every week starting two weeks after planting. Plants were rated on a scale of $1-5$; the rating of $1=$ no disease symptoms; $2=25 \%$ of plant wilted or necrotic; $3=50 \%$ of the plant wilted or necrotic; $4=75 \%$ of the plant wilted or necrotic; $5=$ dead plant (Figure 2.1). Scores were used to determine the area under the disease progress curve (AUDPC). Half of all strawberry crowns from plants that died 
during these assays were plated on APDA to determine if $M p$ was the cause of plant mortality.

The second part of this experiment was designed to assess whether the combination of plant extracts and fungicide drenches were more effective at reducing plant mortality than plant extract drenches alone. Drenches of two different fungicides were also included in this in planta trial. Plant extract drench applications were applied (450 $\mathrm{ml}$ drench per pot) at the $10,000 \mathrm{ppm}$ rate at day 0 to two replicate sets of pots; inoculated and non-inoculated controls pots were also included. All fungicide treatment pots had two teabags each containing a microsclerotia packet. One teabag was recovered on day 3 after the first plant extract drench and before the first fungicide drench. A treatment of either tebuconazole (Tebuzole) or thiophanate-methyl (Topsin) was then applied at the label rate (tebuconazole applied at $3.04 \mathrm{ml}$ per 1.426 gallons of water and thiophanate-methyl applied at $8.43 \mathrm{ml}$ per 1.426 gallons of water) as a $450 \mathrm{ml}$ drench on day 3 to all fungicide pots. The second teabag containing a microsclerotia packet was recovered from the first replicate set of pots three days (day 6) after the application of the first fungicide drench. Microsclerotia packets from all retrieved teabags were slide mounted and analyzed as described earlier. Bare root plants were planted in the first replicate set of pots on day 14; disease assessments starting two weeks after planting on day 28 using the rating system described earlier (Table 3.1).

A second drench of the plant extract (10,000 ppm) was applied to the second set of replicate pots on day 14 . On day 17 , teabags from both the first and second replicate sets of pots was recovered and analyzed as described above. A second fungicide drench of either fungicide was applied to a third replicate set on day 17, three days after the 
second plant extract application. Teabags from the third replicate set of pots was recovered on day 20 and analyzed as described earlier. Transplants were planted in the third set of replicated pots on day 28; disease assessments started on day 42 (Table 3.1).

\section{Statistical analysis}

An analysis of variance (ANOVA) was used to determine the significance of plant extract and fungicide treatment effects on the germination of microsclerotia of $M p$ both in vitro and in planta. Data was transformed using a square root transformation to ensure valid statistical analysis when determining significant differences among treatments. All statistical analyses were conducted using Minitab 16 (Minitab Inc., State College, PA). Plant disease assessment data is currently being collected and will be used to calculate the area under the disease progress curve (AUDPC).

\section{Results}

\section{In vitro germination study}

The number of germinated and non-germinated microsclerotia of $M p$ were recorded for each buried teabag retrieved during this study. Lactophenol blue was used to stain and visualize mycelium (Figure 3.1). Treatment dishes that received a plant extract drench showed a significant increase $(\mathrm{p}<0.001)$ in the percent of microsclerotia that germinated (Figure 3.2; see Appendix C.1). Treatment dishes that only received the water had an increase in the percent of germinated microsclerotia as compared to the dishes that received no drenches (see Appendix C.2). The rates of plant extract concentration had an impact on the percent of germinated microsclerotia with $10 \mathrm{ppm}$ being significantly less 
$(\mathrm{p}<0.001)$ effective, but still significantly higher than both the water and no drench controls. All other extract concentrations showed no significant difference $(\mathrm{p}>0.005)$ among rates (Figure 3.2, Table 3.2; see Appendix C.1).

The number of plant extract drenches (one drench vs two drenches) over time (day 3 vs day 17$)$ were also significant $(p<0.05)$ regarding the mean percent of germinated microsclerotia (Table 3.2; see Appendix C.1). Germination was lower when treatments received only one drench at day 3, but were processed and visualized at day 17 (Table 3.2). Treatments that received two plant extract drenches at day 3 and day 17 had a higher percent germination than those which only received one drench at day 0 and were processed at day 3 (Table 3.2; see Appendix C.2).

\section{In planta germination study}

In planta results were similar to in vitro results. Treatments that received one or more plant extract drenches showed a significant increase $(\mathrm{p}<0.001)$ in the percent of microsclerotia that germinated (Figure 3.3; see Appendix C.3). Treatments that only received a water drench had an increase in the percent of germinated microsclerotia compared to treatments that received no drench. The plant extract concentration had an impact on the percent of germinated microsclerotia, with $10 \mathrm{ppm}$ being less effective, but still significantly higher $(\mathrm{p}<0.05)$ than both water and no drench controls (Figure 3.3). Extract concentrations of 10,000 ppm, 1,000 ppm and 100 ppm had higher germination rates than controls and the $10 \mathrm{ppm}$ treatments, but were not significantly different $(\mathrm{p}>$ 0.05) among themselves (Figure 3.3). 
The number of drenches (one vs. two) over time (day 3 vs. day 17) was not significant $(\mathrm{p}>0.05)$ regarding a change in percent germinated microsclerotia (Table 3.3). All treatments that received a plant extract drench had higher percentages of germinated microsclerotia, but were statistically similar when compared to each other (Table 3.3).

For the second part of this trial, micrsosclerotia of $M p$ were also visualized after the application of both the plant extract and fungicide drenches. Non-living mycelium (from germinated microsclerotia) was differentiated from living intact mycelium by staining mycelium with a $2 \%$ lactophenol blue solution (Figure 3.4). The number of drenches of either fungicide following a drench of plant extract at the concentration of 10,000 ppm significantly lowered the number of living germinated microsclerotia with intact mycelium ( $\mathrm{p}$ < 0.001) (Figure 3.5, Table 3.4; see Appendix C.3). If only one fungicide drench was applied on day 3, thiophanate-methyl would be the optimal fungicide as it had a lower percent of germinated microsclerotia with intact mycelium than the 10,000 ppm extract alone (Table 3.4). If two drenches of fungicide are applied following drenches of the plant extract, both tebuconazole and thiophanate-methyl worked as effectively and were not significantly different $(p>0.05)$ from each other, but were significantly lower $(\mathrm{p}<0.05)$ than the 10,000 ppm extract alone (Table 3.4; see Appendix C.3).

Plant disease assessments are currently being collected, but are not complete at this time. The project will be concluded June 11, 2016 at which time the data will be entered and analyzed. 


\section{Discussion}

The use of whole strawberry plant extracts can be used to induce the germination of microsclerotia of $M p$. In both in vitro and in planta trials, an increase in the amount of germinated microsclerotia was observed. Every concentration tested had higher germination rates than the water control, with the $10 \mathrm{ppm}$ extract showing the least amount of microsclerotia germination.

It is unclear whether two drenches of the plant extracts are preferable to a single drench. In vitro experiments show a significant increase in the number of germinated microsclerotia after the second extract drench, but in planta data showed no significant differences between the numbers of extract drenches. Regarding the integration of fungicide drenches with plant extract drenches, it seems clear that a fungicide drench following a plant extract drench is more effective when the combination is applied twice rather than just a single application of each. The integrated portion of the trial shows that using plant extracts and fungicide drenches in combination may help to reduce the number of viable microsclerotia in the soil.

The use of germination stimulants made from strawberry plant tissue has the potential to assist fungicides for the control of soilborne pathogens of strawberry if coupled with the most effective fungicides (tebuconazole and thiophanate-methyl). Results from our earlier fungicide trials (Chapter 2 of this thesis) showed that soil-applied fungicides alone were not effective at controlling both Macrophomina crown rot and Fusarium wilt. It will be necessary to integrate multiple tactics in order to effectively manage these two emerging soilborne threats to California strawberry production. 
Due to the time restraints of completing this thesis, data is still being collected from the in planta trial, but will be analyzed after June 11, 2016 when the study is completed. In order for all in planta data to be more relevant, the entire experiment needs to be repeated in field settings, where the extracts can be applied through drip irrigation at different timings. It would also be important to show whether the pathogens respond to extracts from a variety of strawberry cultivars and whether or not an alternative crop may be used in place of strawberry in making the germination stimulant, i.e. one that is easier to extract or from a plant that is easier to harvest. 
Table 3.1. Timeline of various treatment applications and data collection during the in planta trial.

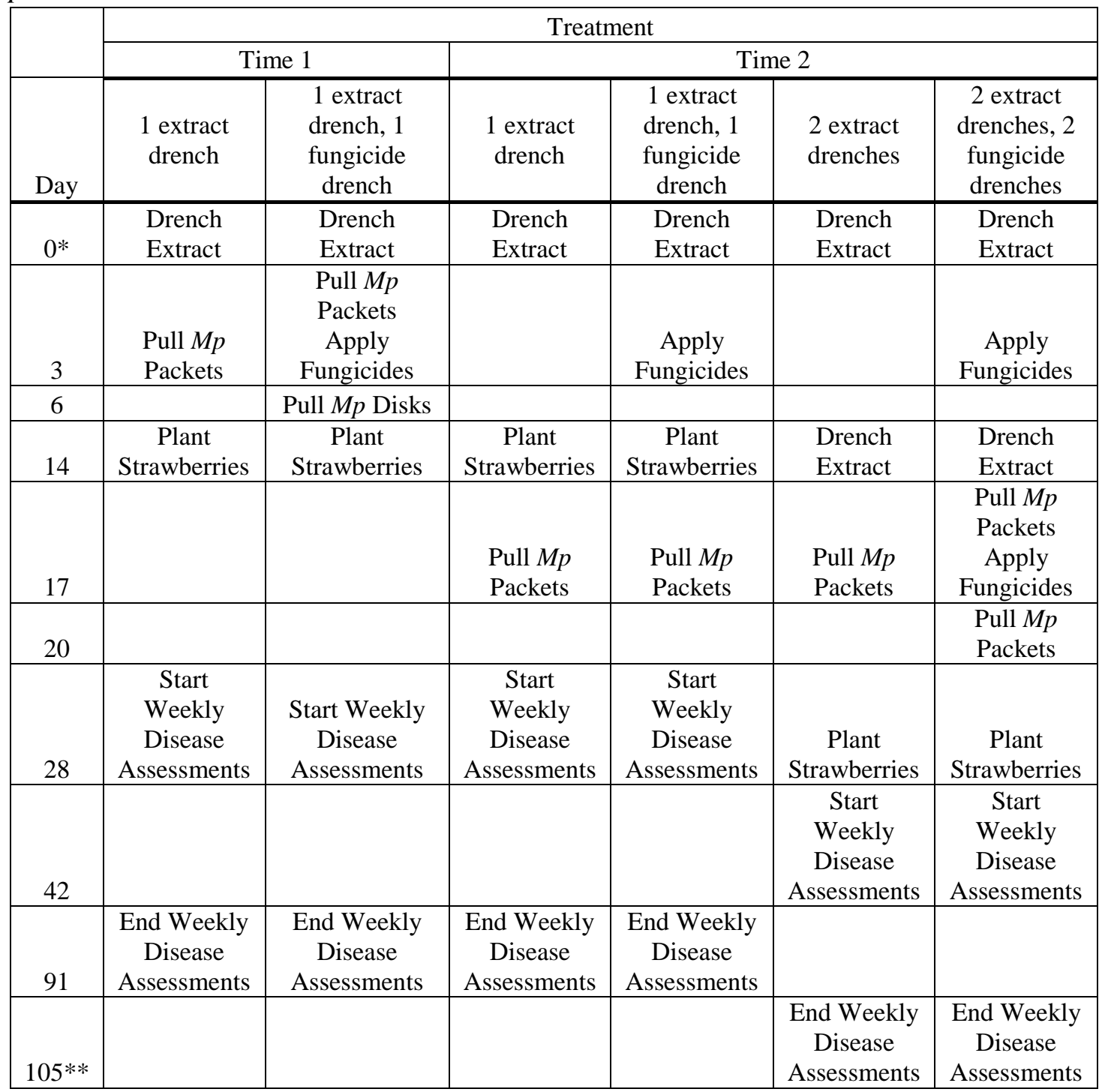

*Day 0 corresponds to February 27, 2016.

** Day 105 corresponds to June 11, 2016. 


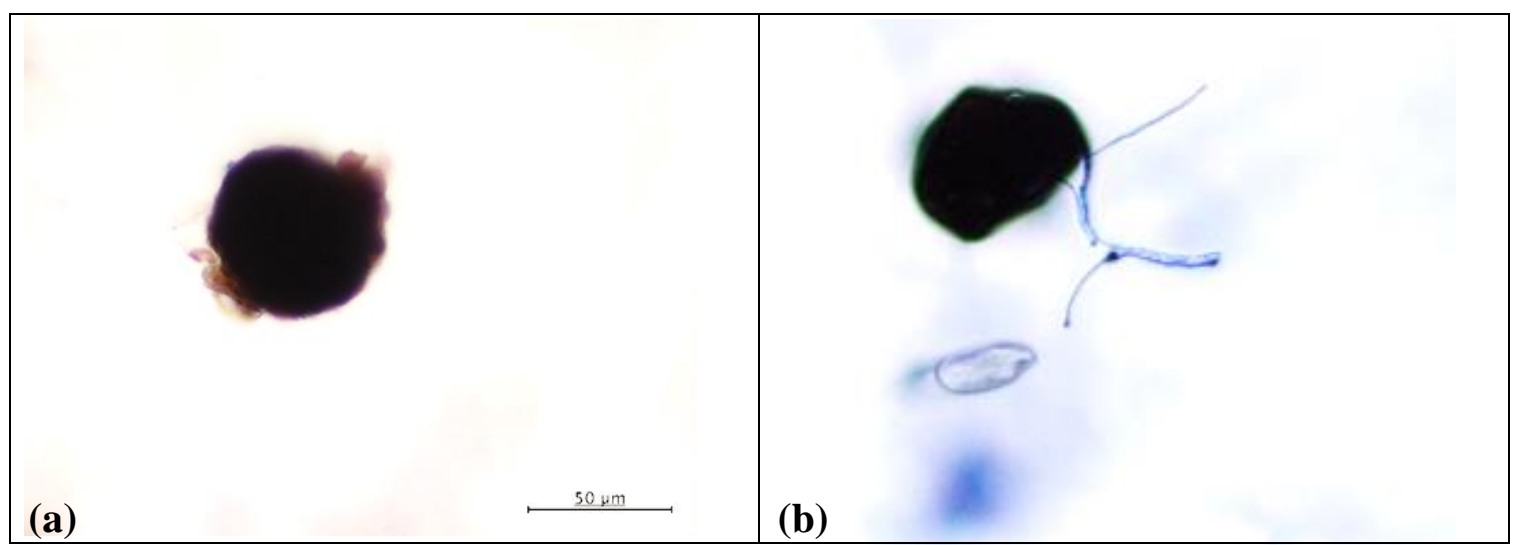

Figure 3.1. Microsclerotia of Macrophomina phaseolina that (a) did not germinate, and (b) did germinate.

The mycelium has been stained with $2 \%$ lactophenol blue. 
घ Time* 1 Drench 1 a Time 2 Drench 1 - Time 2 Drench 2

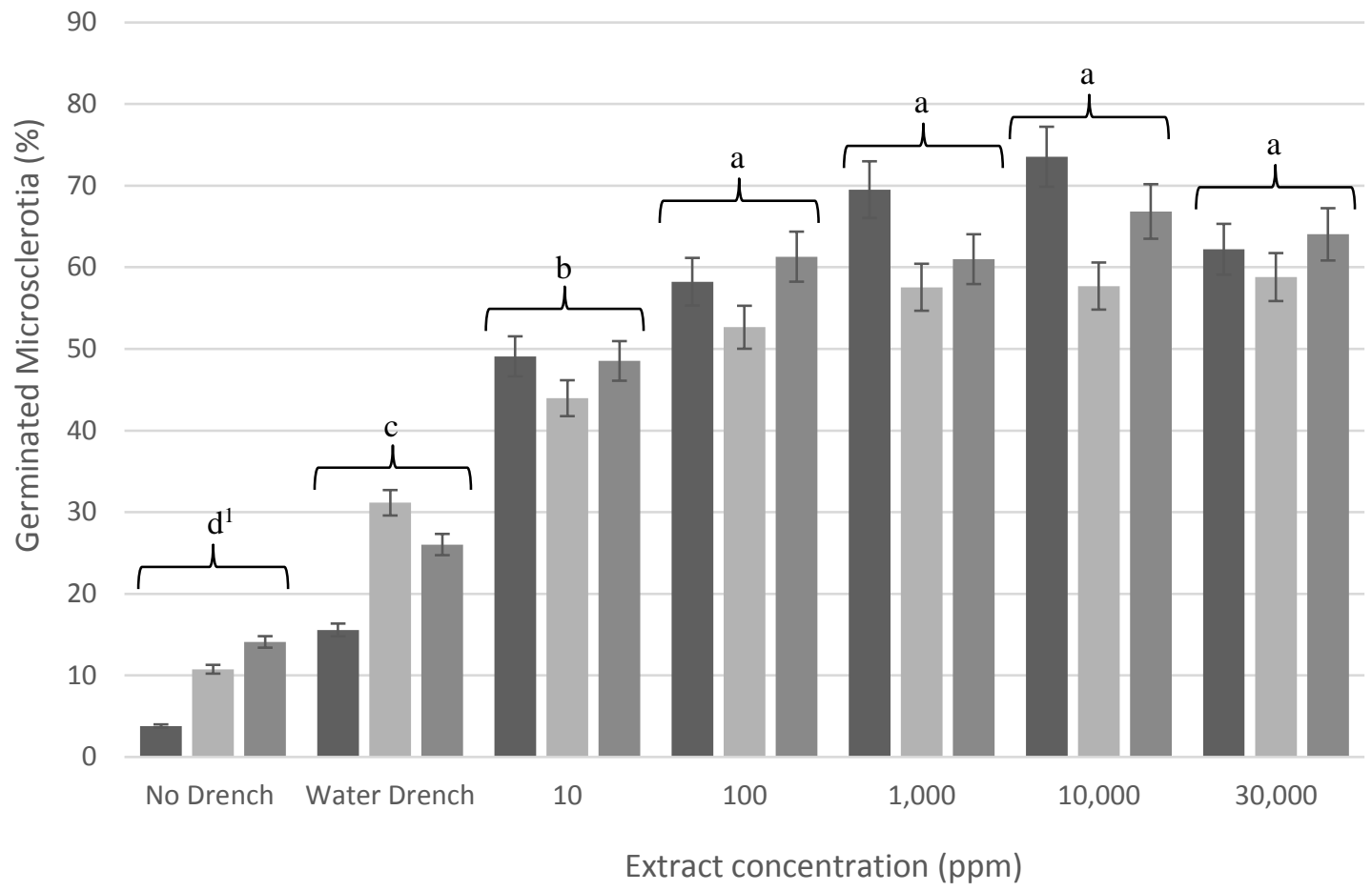

Figure 3.2. Percent of Macrophomina phaseolina microsclerotia that germinated after treatment drench in vitro.

*Days based on day microsclerotia were counted.

${ }^{1}$ Grouping based on $90 \%$ simultaneous confidence intervals. Means that do not share the same letter are significantly different. Groupings are based on the means of six reps of each treatment over two repeated trials.

See Appendix C.1 for data analysis. 
Table 3.2. Percent of Macrophomina phaseolina microsclerotia that germinated after treatment drench for two repeated trials in vitro.

\begin{tabular}{lccc|ccc}
\hline & \multicolumn{3}{c|}{ Trial I } & \multicolumn{3}{c}{ Trial II } \\
\cline { 2 - 7 } Treatment & $\begin{array}{c}\text { Day 3, } \\
\text { 1 Drench }\end{array}$ & $\begin{array}{c}\text { Day 21, } \\
\text { 1 Drench }\end{array}$ & $\begin{array}{c}\text { Day 21, } \\
\text { 2 Drenches }\end{array}$ & $\begin{array}{c}\text { Day 3, } \\
\text { 1 Drench }\end{array}$ & $\begin{array}{c}\text { Day 21, } \\
\text { 1 Drench }\end{array}$ & $\begin{array}{c}\text { Day 21, } \\
\text { 2 Drenches }\end{array}$ \\
\hline No drench & 2.87 & 9.53 & 11.96 & 4.74 & 11.98 & 16.25 \\
Water drench & 16.89 & 31.70 & 24.35 & 14.25 & 30.60 & 27.72 \\
10 ppm extract & 46.53 & 30.30 & 41.59 & 51.65 & 57.63 & 55.48 \\
100 ppm extract & 60.52 & 42.61 & 64.46 & 55.96 & 62.71 & 58.15 \\
1,000 ppm extract & 71.00 & 56.80 & 60.00 & 68.03 & 58.32 & 62.01 \\
10,000 ppm extract & 71.05 & 52.54 & 61.95 & 76.04 & 62.87 & 71.74 \\
30,000 ppm extract & 57.91 & 53.80 & 64.22 & 66.52 & 63.81 & 63.86 \\
\hline
\end{tabular}




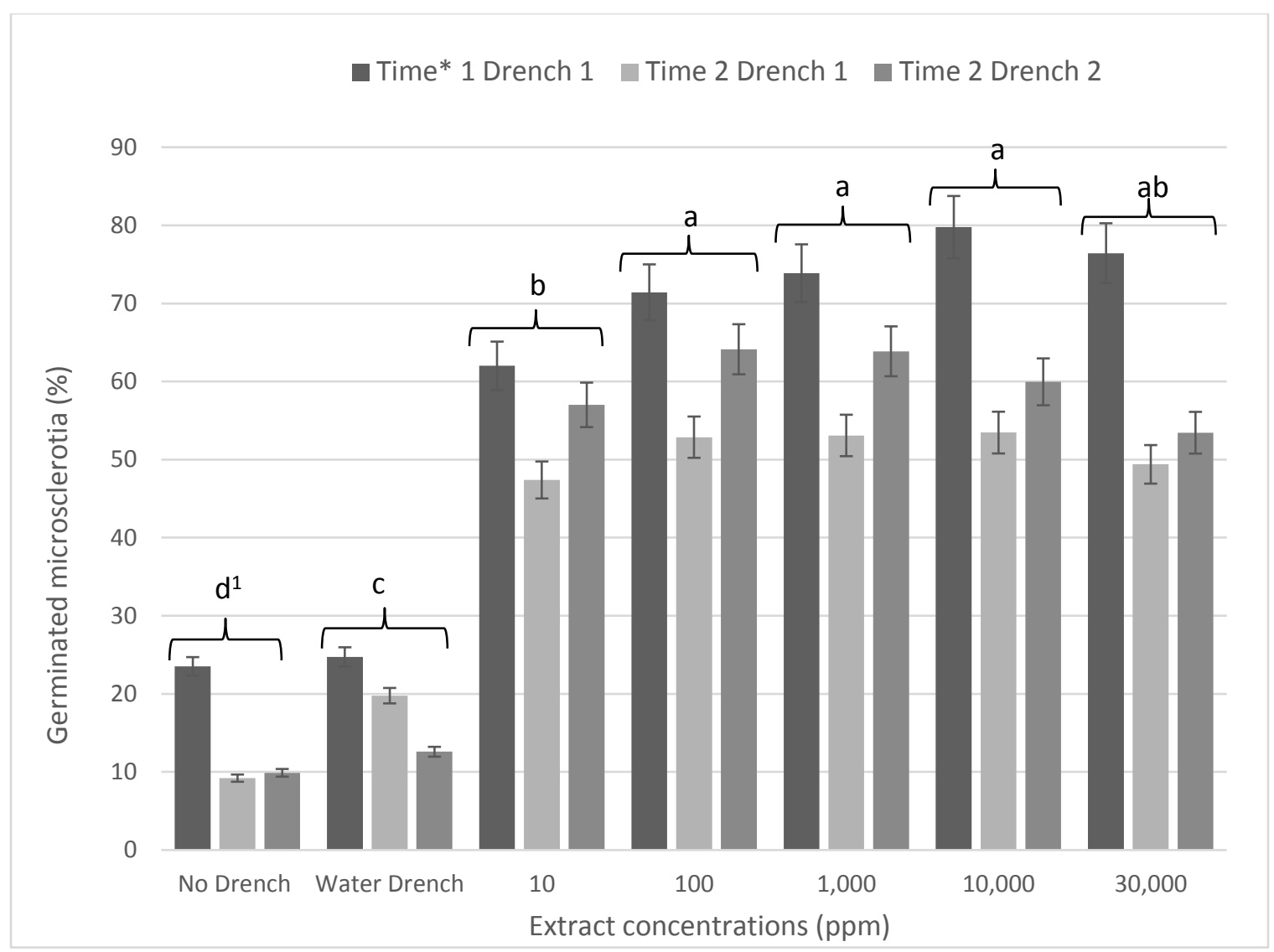

Figure 3.3. Percent of Macrophomina phaseolina microsclerotia that germinated after treatment drench in planta.

*Days based on day microsclerotia were counted.

${ }^{1}$ Grouping based on $90 \%$ simultaneous confidence intervals. Means that do not share the same letter are significantly different. Groupings are based on the mean of six reps of each treatment.

See Appendix C.3 for data analysis. 
Table 3.3. Percent of Macrophomina phaseolina microsclerotia that germinated after specific in planta trial treatments.

\begin{tabular}{lccc}
\hline & Day $3 *, 1$ drench & Day 17,1 drench & Day 17, 2 drenches \\
\cline { 2 - 4 } Treatment & \% germinated & \% germinated & \% germinated \\
\hline No drench & $23.53 \mathrm{~g}^{1}$ & $9.21 \mathrm{i}$ & $9.89 \mathrm{i}$ \\
Water drench & $24.73 \mathrm{~g}$ & $19.77 \mathrm{gh}$ & $12.59 \mathrm{hi}$ \\
10 ppm extract & $62.01 \mathrm{~b}-\mathrm{f}$ & $47.39 \mathrm{f}$ & $57.01 \mathrm{c}-\mathrm{f}$ \\
$100 \mathrm{ppm}$ extract & $71.43 \mathrm{a}-\mathrm{c}$ & $52.87 \mathrm{~d}-\mathrm{f}$ & $64.13 \mathrm{a}-\mathrm{e}$ \\
1,000 ppm extract & $73.87 \mathrm{ab}$ & $53.09 \mathrm{~d}-\mathrm{f}$ & $63.87 \mathrm{a}-\mathrm{e}$ \\
10,000 ppm extract & $79.77 \mathrm{a}$ & $53.46 \mathrm{~d}-\mathrm{f}$ & $59.96 \mathrm{~b}-\mathrm{f}$ \\
30,000 ppm extract & $76.44 \mathrm{ab}$ & $49.39 \mathrm{ef}$ & $53.44 \mathrm{~d}-\mathrm{f}$ \\
\hline
\end{tabular}

*Days based on day microsclerotia were counted.

${ }^{1}$ Grouping based on a square root transformation and $90 \%$ simultaneous confidence intervals. Means that do not share the same letter are significantly different. Groupings are based on the mean of six reps of each treatment.

See Appendix C.3 for data analysis. 


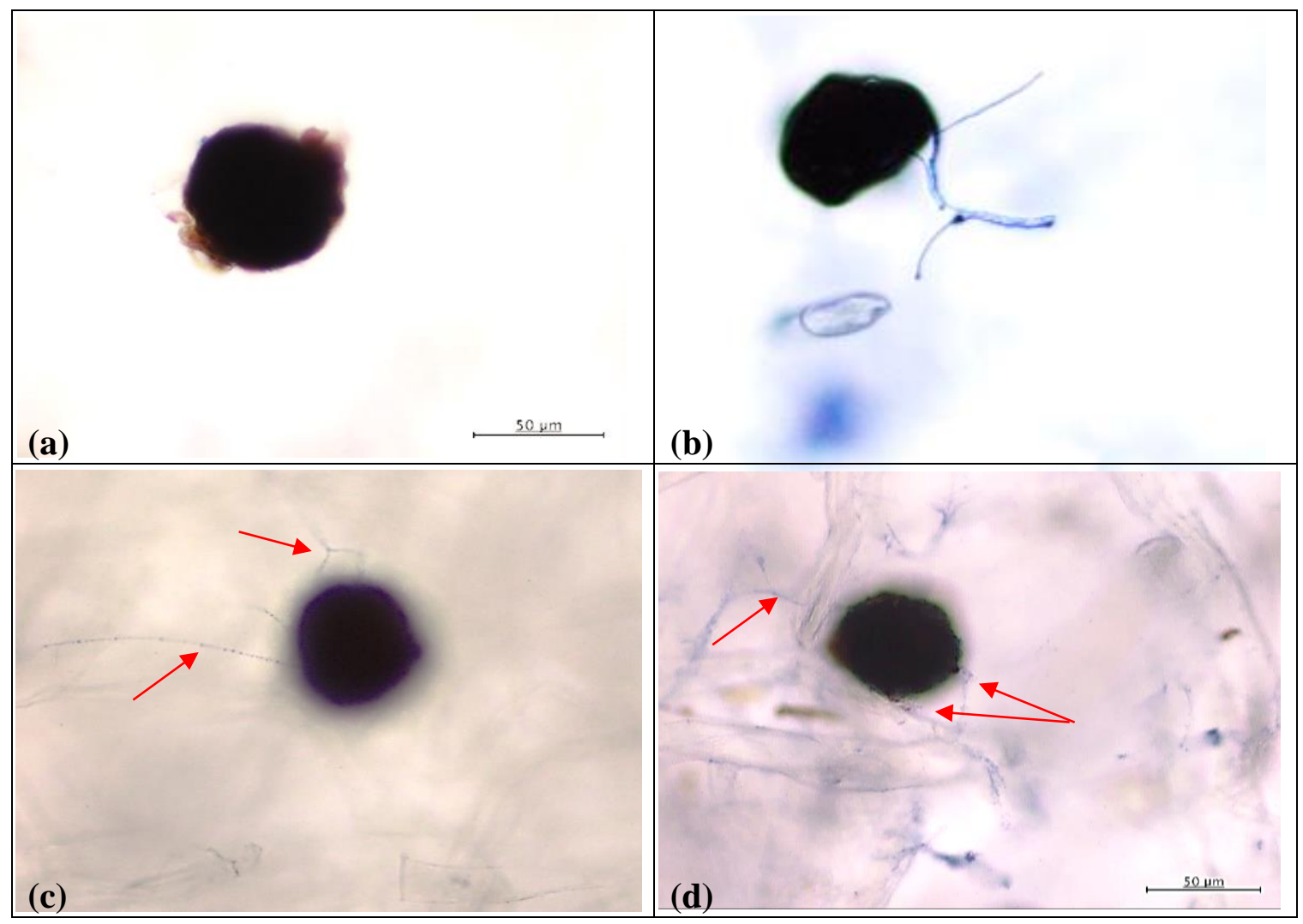

Figure 3.4. Microsclerotia of Macrophomina phaseolina that (a) did not germinate, and (b) did germinate. Microsclerotia in (c) and (d) did germinate, but the mycelium is no longer intact (red arrows). The mycelium has been stained with $2 \%$ lactophenol blue. 
- Time* 1 Drench 1 Time 2 Drench 2

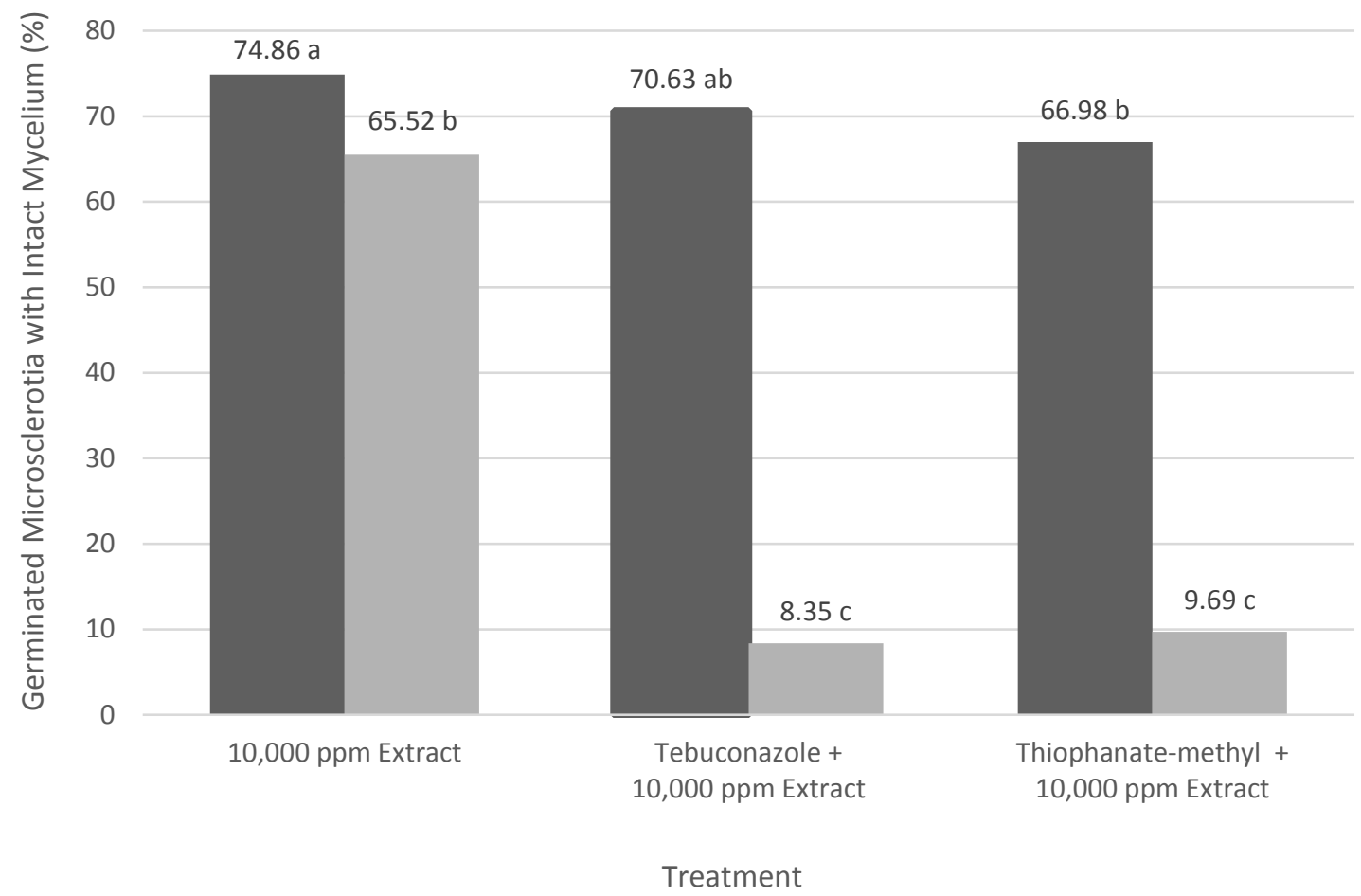

Figure 3.5. Percent of germinated Macrophomina phaseolina microsclerotia with intact mycelium after drenches of plant extracts and fungicides in planta.

*Days based on day microsclerotia were counted.

${ }^{1}$ Grouping based on a square root transformation with $90 \%$ simultaneous confidence intervals. Means that do not share the same letter are significantly different. Groupings are based on the mean of six reps of each treatment.

See Appendix C.3 for data analysis. 
Table 3.4. Percent of germinated Macrophomina phaseolina microsclerotia with intact mycelium after drenches of plant extracts and fungicides in planta.

\begin{tabular}{lcc}
\hline & Day $3^{*}, 1$ Drench & Day 17,2 Drenches \\
\cline { 2 - 3 } Treatment & $\begin{array}{c}\text { \% germinated } \\
\text { microsclerotia }\end{array}$ & $\begin{array}{c}\text { \% germinated } \\
\text { microsclerotia }\end{array}$ \\
\hline 10,000 ppm extract & $74.86 \mathrm{a}^{1}$ & $65.52 \mathrm{~b}$ \\
Tebuconazole $+10,000 \mathrm{ppm}$ extract & $70.63 \mathrm{ab}$ & $8.35 \mathrm{c}$ \\
Thiophanate-methyl $+10,000$ ppm extract & $66.98 \mathrm{~b}$ & $9.69 \mathrm{c}$ \\
\hline
\end{tabular}

*Days based on day microsclerotia were counted.

${ }^{1}$ Grouping based on $90 \%$ simultaneous confidence intervals. Means that do not share the same letter are significantly different. Groupings are based the mean of six reps of each treatment. 


\section{REFERENCES}

1. Aviles, M., Castillo, S., Bascon J., Zea-Bonilla, T., Martin-Sanchez, P. M., and Perez-Jimenez R. M. 2008. First report of Macrophomina phaseolina causing crown and root rot of strawberry in Spain. Plant Pathol. 57:382-383.

2. Baino, O., Salazar, S. M., Ramallo, A. C., and Kirschbaum, D. S. 2011. First report of Macrophomina phaseolina causing strawberry crown and root rot in northwestern Argentina. DOI: 10.1094/PDIS-03-11-0193.

3. Baird, R. E., Watson, C. E., and Scruggs, M. 2003. Relative longevity of Macrophomina phaseolina and associated mycobiota on residual soybean roots in soil. Plant Dis. 87:563-566.

4. Baudry, A. and Morzieres, J. P. 1993. First report of charcoal rot of strawberry in France. Acta. Hort. 348:485-488.

5. Brayford, D. 1996. Fusarium oxysporum f. sp. fragariae. Mycopathologia $133: 45-46$

6. California Strawberry Commission. 2015. About strawberries. 15 October 2015. <http://www.californiastrawberries.com/about_strawberries >.

7. Cloud, G. L. and Rupe, J. C. 1991. Comparison of three media for enumeration of sclerotia of Macrophomina phaseolina. Plant Dis. 75:771-772.

8. Coventry, E., Noble, R., Mead, A. and Whipps, J. M. 2002. Control of allium white rot (Sclerotium cepivorum) with composted onion waste. Soil Biology \& Biochemistry 34:1037-1045.

9. Crowe, F. J., Debons, J., Thornton, M., Koepsell, P., McGrath, D., Darnell, T., Davis, M., Laborde, J., and Redondo Jaurez, E. 1992. Use of stimulants of sclerotial germination to manage inoculum density of Sclerotium cepivorum and to control white rot of onions and garlic. Oregon State University.

10. Davis, R. M., Hao, J. J., Romberg, M. K., Nunez, J. J., and Smith, R. F. 2007. Efficacy of germination stimulants of sclerotia of Sclerotium cepivorum for management of white rot of garlic. Plant Dis. 91:204-208.

11. De Cal, A., Martinez-Treceno, A., Salto, T., Lopez-Aranda, J. M. and Melgarejo, P. 2005. Effect of chemical fumigation on soil fungal communities in Spanish strawberry nurseries. Applied Soil Ecology 28:47-56. 
12. Fang, X., Kuo, J., You, M. P., Finnegan, P. M., Barbetti, M. J., 2012. Comparative root colonization of strawberry cultivars Camarosa and Festival by Fusarium oxysporum f. sp. fragariae. Plant and Soil 358:75-89.

13. Fennimore, S. and Daugovish, O., 2012. Weed management in strawberry. California Strawberry Commission Annual Production Research Report: 20112012.

14. Fennimore, S., Miller, T., Goodhue, R. and Subbarao, K. 2012. Evaluation of an automatic steam applicator in strawberry. In: Proc Ann Int Res Conf on Methyl Bromide Alternatives and Emissions Reductions, Nov. 6-8, 2012. Maitland, FL. Abstr. 9. www.mbao.org/

15. Ferry, A. and Davis, R. M. 2012. Combining sclerotia germination stimulants and fungicides for control of white rot of onions and garlic. Phytopathology 102:3839.

16. Fravel, D., Olivain, C., Alabouvette, C., 2003. Fusarium oxysporum and its biocontrol. New Phytologist 157:493-502.

17. Gordon, T. R., Koike, S. T. and Daugovish, O. 2013. Management of diseases caused by Fusarium oxysporum, Verticillium dahliae and Macrophomina phaseolina. California Strawberry Commission Annual Production Research Report: 9-21.

18. Gupta, G. K., Sharma, S. K. and Ramteke, R. 2012. Biology, epidemiology and management of the pathogenic fungus Macrophomina phaseolina (Tassi) Goid with special reference to charcoal rot of soybean (Glycine max (L.) Merrill). Journal of Phytopathology 160:167-180.

19. Hovius, M. H. Y., and McDonald, M. R. 2002. Management of Allium white rot Sclerotium cepivorum in onions on organic soil with soil-applied diallyl disulfide and di-N-propyl disulfide. Canadian Journal of Plant Pathology-Revue Canadienne De Phytopathologie 24:281-286.

20. Isakeit, T., Minzenmayer, R. R., Drake, D. R., Multer, W., Abrameit, A., Jungman, M., Crossland, C., Campion, D. T., Fryar, N., Morgan, G. and Mott, D. 2011. Flutriafol for control of phymatotrichopsis root rot of cotton beltwide Cotton Prod. Res. Conf. 2011:207.

21. Islas, C. M., Gordon, T. R., Daugovish, O. and Koike, S. 2011. Fusarium wilt of strawberry, caused by Fusarium oxysporum f. sp. fragariae, a new disease in California. Phytopathology 101:S79. 
22. Kaur, S., Dhillon, G. S., Brar, S. K., Vallad, G. E., Chand, R. and Chauhan, V. B. 2012. Emerging phytopathogen Macrophomina phaseolina: biology, economic importance and current diagnostic trends. Critical Reviews in Microbiology 38:136-151.

23. Kim, C. H., Seo, H. D., Cho, W. D. and Kim, S. B., 1982. Studies on varietal resistance and chemical control to the wilt of strawberry caused by Fusarium oxysporum. Korean J. Plant Prot. 21:61-67.

24. Koike, S. and Bolda, M. Charcoal rot of strawberry: Increasing problem in California (blog). University of California Extension. August 2, 2013. http://ucanr.edu/blogs/blogcore/postdetail.cfm?postnum=11043.

25. Koike, S. T., Kirkpatrick, S. C. and T. R. Gordon. 2009. Fusarium wilt of strawberry caused by Fusarium oxysporum in California. Plant Dis 93:1077.

26. Koike, S., 2012, Continuing development of management strategies for charcoal rot (Macrophomina phaseolina) of strawberry in California. California Strawberry Commission Annual Production Research Report: 2011-2012.

27. Koike, S. T. and Gordon, T. R. 2015. Management of Fusarium wilt of strawberry. Crop Prot. 73:67-72.

28. Koike, S. T., Gordon, T. R., Daugovish, O., Ajwa, H., Bolda, M. and Subbarao, K. 2013a. Recent developments on strawberry plant collapse problems in California caused by Fusarium and Macrophomina. International Journal of Fruit Science 13:1-2.

29. Koike, S. T., Gordon, T. R., Daugovish, O. and Ajwa, H. 2013b. Fusarium wilt of strawberry: Production Guidelines. California Strawberry Commission.

30. Koike, S. T., Gordon, T. R., Daugovish, O., Ajwa, H. and Martin, F. $2013 \mathrm{c}$. Charcoal rot of strawberry: Production Guidelines. California Strawberry Commission.

31. Leahy, B. R., Browne, G., Fennimore, S., Katten, A., Klonsky, K., Koda, R., Legard, D., Marrone, P., Obenauf, G., Shennan, C. and Steggall, J. 2013. Nonfumigant strawberry production working group action plan. California Department of Pesticide Regulation.

32. Lin, Y. J., He, Z. L., Rosskopf, E. N., Conn, K. L., Powell, C. A., and Lazarovits, G. 2010. A nylon membrane bag assay for determination of the effect of chemicals on soilborne plant pathogens in soil. Plant Dis. 94:201-206. 
33. Maas, J. L. 1998. Compendium of strawberry diseases. 2nd Ed. APS Press, St. Paul, MN. Pg 28-31.

34. Martin, F. 2003. Development of alternative strategies for management of soilborne pathogens currently controlled with methyl bromide. Annual Review of Phytopathology 41:325-350.

35. Mattner, S. W. 2008. Factors that impact on the ability of biofumigants to suppress fungal pathogens and weeds of strawberry. Crop Prot. 27:1165-1173.

36. Mertely, J., Seijo, T. and Peres, N. A. 2005. First report of Macrophomina phaseolina causing a crown rot of strawberry in Florida. Plant Dis. 89:434.

37. Mertely, J., Seijo, T., Martin, R., and Peres, N. A. 2014. Evaluation of chemical and biological treatments for charcoal rot control in annual strawberry. Plant Disease Management Reports 8:SMF026.

38. Mertely, J., Seijo, T., Martin, R., Moore, D. and Peres, N. A. 2010. Evaluation of products to control charcoal rot in annual strawberry. Plant Disease Management Reports 5:SMF019.

39. Mihail, J. D. 1992. Macrophomina. Methods for research on soilborne phytopathogenic fungi. L.S. Singleton, J. D. Mihail, and Rush, C. M. eds. American Phytophtological Society, St Paul, MN. Pages 134-136.

40. Mihail, J. D. and Alcorn, S. M. 1982. Quantitative recovery of Macrophomina phaseolina sclerotia from soil. Plant Dis. 66:662-663.

41. Okamoto, H., Fujii, S., Kato, K. andYoshioka, A., 1970. A new strawberry disease 'Fusarium wilt'. Plant Prot. 24:231-235.

42. Olaya, G., and Abawi, G. S. 1996. Effect of water potential on mycelial growth and production and germination of sclerotia of Macrophomina phaseolina. Plant Dis. 80:1347-1350.

43. Shaw, D. V., and Larson, K. D. 1996. Relative performance of strawberry cultivars from California and other North American sources in fumigated and nonfumigated soils. J American Society for Horticultural Sci. 121:764-767.

44. Shaw, D. V., and Larson, K. D. 1999. A meta-analysis of strawberry yield response to preplant soil fumigation with combinations of methyl bromidechloropicrin and four alternative systems. Horticultural Science 34:839-845.

45. Shennan, C., Muramoto, J., Baird, G., Fennimore, S., Koike, S., Bolda, M., Daugovish, O., Dara, S., Mazzola, M., and Lazarovits, G. 2012. Non-fumigant strategies for soilborne disease control in California strawberry production 
systems. In: Proc Ann Int Res Conf on Methyl Bromide Alternatives and Emissions Reductions, Nov. 6-8, 2012. Maitland, FL. Abstr. 9. www.mbao.org/

46. Simko, I., and Piepho, H-P. 2012. The area under the disease progress stairs: Calculation, advantage, and application. Phytopathology 102:381-389.

47. Smith, G. S. and Carvil, O. N. 1977. Field screening of commercial and experimental soybean cultivars for their reaction to Macrophomina phaseolina. Plant Dis. 81:363-368.

48. US EPA. 1999. Protection of stratospheric ozone: incorporation of Montreal Protocol adjustment for a 1999 interim reduction in class I, group VI controlled substances. Federal Register 64:29240-29245.

49. Voth, V., Bringhurst, R. S. 1990. Culture and physiological manipulation of California strawberries. HortScience 25:889-892.

50. Wilhelm, S. and Paulus, A. O. 1980. How soil fumigation benefits the California strawberry industry. Plant Dis. 64:264-270.

51. Winks, B. L. and Williams, Y. N., 1965. A wilt of strawberry caused by a new form of Fusarium oxysporum. Queensl. J. Agr. Anim. Sci. 22:475-479.

52. Wyllie, T. D., Gangopadhyay, S., Teague, W. R. and Blanchar, R. W. 1984. Germination and production of Macrophomina phaseolina microsclerotia as affected by oxygen and carbon dioxide concentration. Plant and Soil 81:195-201.

53. Yuen, G. Y., Schroth, M. N., Winhold, A. R., and Hancock, J. G. 1991. Effects of soil fumigation with methyl bromide and chloropicrin on root health and yield of strawberry. Plant Dis. 75:416-420.

54. Zveibil, A. and Freeman, S. 2005. First report of crown and root rot in strawberry caused by Macrophomina phaseolina in Israel. Plant Dis. 89:1014.

55. Zveibil, A., Mor, N., Gnayem, N., and Freeman, S. 2012. Survival, host-pathogen interaction, and management of Macrophomina phaseolina on strawberry in Israel. Plant Dis. 96:265-272. 


\section{APPENDICES}

\section{Appendix A. Regression Analysis for In Vitro Fungicide Assays}

\section{A 1. In vitro fungicide assays for Macrophomina phaseolina (Mp) isolates}

Table A 1.1. Regression equations for in vitro fungicide assays $M p 13$ day 34 (Table 2.2)

\begin{tabular}{lccc}
\hline \multicolumn{1}{c}{ Fungicide } & Transformation & Equation & r-squared \\
\hline Tebuconazole & $100-$ Y 5 by $\log _{10}$ rate & EC value $=63.32+24.61$ lograte & 92.4 \\
Metconazole & $100-$ Y5 by $\log _{10}$ rate & EC value $=62.71+25.97$ lograte & 93.7 \\
Flutriafol & $100-$ Y5 by rate & EC value=10.05 +1.377 rate & 76.9 \\
Penthiopyrad & $100-$ Y5 by $\log _{10}$ rate & EC value $=62.27+16.62$ lograte & 89.4 \\
Fluopyram & $100-Y 5$ by rate & EC value $=33.43+4.498$ rate & 72.2 \\
Flutolanil & $100-Y 5^{2}$ by rate & EC value $=0.490+0.3368$ lograte & 29.3 \\
Fludioxonil & $100-Y 5$ by Log $_{10}$ rate & EC value $=87.13+16.24$ lograte & 80.3 \\
\hline
\end{tabular}

Table A 1.2. Regression equations for in vitro fungicide assays $M p 13$ day 50 (Table 2.2)

\begin{tabular}{|c|c|c|c|}
\hline Fungicide & Transformation & Equation & r-squared \\
\hline Tebuconazole & $100-Y 5$ by $\log _{10}$ rate & EC value $=63.24+24.53$ lograte & 92.6 \\
\hline Metconazole & $100-Y 5$ by $\log _{10}$ rate & $\mathrm{EC}$ value $=62.95+26.10$ lograte & 93.7 \\
\hline Flutriafol & $100-Y 5^{2}$ by rate & $\mathrm{EC}_{\text {value }}^{2}=248.7+105.9$ rate & 95.7 \\
\hline Penthiopyrad & $100-Y 5$ by $\log _{10}$ rate & EC value $=62.27+16.62$ lograte & 89.4 \\
\hline Fluopyram & $100-Y 5^{2}$ by rate & $\mathrm{EC}_{\text {value }}^{2}=33.43+4.498$ rate & 72.2 \\
\hline Flutolanil & $100-Y 5^{2}$ by rate & $\mathrm{EC} \mathrm{value}^{2}=0.077+0.0585$ lograte & 26 \\
\hline Fludioxonil & $100-Y 5$ by $\log _{10}$ rate & EC value $=87.13+16.24$ lograte & 80.2 \\
\hline
\end{tabular}

Table A 1.3. Regression equations for in vitro fungicide assays $M p 8$ day 34 (Table 2.2)

\begin{tabular}{|c|c|c|c|}
\hline Fungicide & Transformation & Equation & r-squared \\
\hline Tebuconazole & $100-Y 5$ by $\log _{10}$ rate & EC value $=69.68+22.96$ lograte & 80.7 \\
\hline Metconazole & $100-Y 5$ by $\log _{10}$ rate & $\mathrm{EC}$ value $=66.72+25.00$ lograte & 88.1 \\
\hline Flutriafol & $100-Y 5$ by $\log _{10}$ rate & $\mathrm{EC}$ value $=34.71+23.05$ lograte & 92.2 \\
\hline Penthiopyrad & $100-Y 5$ by $\log _{10}$ rate & $\mathrm{EC}$ value $=55.85+26.99$ lograte & 96.4 \\
\hline Fluopyram & $100-Y 5$ by $\log _{10}$ rate & $\mathrm{EC}$ value $=40.62+25.52$ lograte & 90.5 \\
\hline Flutolanil & $100-Y 5$ by rate & $\mathrm{EC}$ value $=1.925+0.487$ lograte & 58.1 \\
\hline Fludioxonil & $100-Y 5$ by $\log _{10}$ rate & $E C$ value $=86.96+14.39$ lograte & 73.7 \\
\hline
\end{tabular}


Table A 1.4. Regression equations for in vitro fungicide assays $M p 8$ day 50 (Table 2.2)

\begin{tabular}{lclc}
\hline \multicolumn{1}{c}{ Fungicide } & Transformation & Equation & r-squared \\
\hline Tebuconazole & $100-$ Y5 by $\log _{10}$ rate & EC value=69.64 +22.95 lograte & 80.6 \\
Metconazole & $100-$ Y5 by $\log _{10}$ rate & EC value=66.69 +24.95 lograte & 88 \\
Flutriafol & $100-$ Y5 by $\log _{10}$ rate & EC value $=34.71+23.05$ lograte & 92.2 \\
Penthiopyrad & $100-$ Y5 by $\log _{10}$ rate & EC value $=55.88+27.02$ lograte & 96.5 \\
Fluopyram & $100-$ Y5 by $\log _{10}$ rate & EC value=40.62 +25.52 lograte & 90.5 \\
Flutolanil & $100-$ Y5 by rate & EC value $=1.925+0.487$ lograte & 58.1 \\
Fludioxonil & $100-$ Y5 by $\log _{10}$ rate & EC value $=86.96+14.39$ lograte & 73.6 \\
\hline
\end{tabular}

\section{A 2. In vitro fungicide assays for Fusarium oxysporum f. sp. fragariae (Fof) isolates}

Table A 1.5. Regression equations for in vitro fungicide assays Fof 10.3 day 34 (Table 2.2)

\begin{tabular}{|c|c|c|c|}
\hline Fungicide & Transformation & Equation & r-squared \\
\hline Tebuconazole & $100-Y 5$ by $\log _{10}$ rate & $\mathrm{EC}$ value $=50.09+27.14$ lograte & 92.1 \\
\hline Metconazole & $100-Y 5$ by $\log _{10}$ rate & $\mathrm{EC}$ value $=73.86+24.28$ lograte & 88.3 \\
\hline Flutriafol & $100-Y 5$ by $\log _{10}$ rate & $\mathrm{EC}$ value $=11.16+25.75$ lograte & 89.1 \\
\hline Penthiopyrad & $100-Y 5$ by $\log _{10}$ rate & $\mathrm{EC}$ value $=1.775+4.18$ lograte & 22.1 \\
\hline Fluopyram & $100-Y 5$ by $\log _{10}$ rate & $\mathrm{EC}$ value $=3.452+2.644$ lograte & 17.2 \\
\hline Flutolanil & $100-Y 5$ by $\log _{10}$ rate & $\mathrm{EC}$ value $=5.882+5.595$ lograte & 46.7 \\
\hline Fludioxonil & $100-Y 5$ by $\log _{10}$ rate & $\mathrm{EC}$ value $=13.36+3.221$ lograte & 18.3 \\
\hline
\end{tabular}

Table A 1.6. Regression equations for in vitro fungicide assays Fof 10.3 day 50 (Table 2.2)

\begin{tabular}{|c|c|c|c|}
\hline Fungicide & Transformation & Equation & r-squared \\
\hline Tebuconazole & $100-Y 5$ by $\log _{10}$ rate & EC value $=49.24+26.65$ lograte & 92.5 \\
\hline Metconazole & $100-Y 5$ by $\log _{10}$ rate & EC value $=73.60+24.14$ lograte & 88.2 \\
\hline Flutriafol & $100-Y 5$ by $\log _{10}$ rate & EC value $=11.58+26.22$ lograte & 88.5 \\
\hline Penthiopyrad & $100-Y 5$ by $\log _{10}$ rate & $\mathrm{EC}$ value $=0.925+3.223$ lograte & 22.1 \\
\hline Fluopyram & $100-Y 5$ by $\log _{10}$ rate & $\mathrm{EC}$ value $=3.452+2.644$ lograte & 17.2 \\
\hline Flutolanil & $100-Y 5$ by $\log _{10}$ rate & $\mathrm{EC}$ value $=5.882+5.595$ lograte & 46.7 \\
\hline Fludioxonil & $100-Y 5$ by $\log _{10}$ rate & $\mathrm{EC}$ value $=13.36+3.221$ lograte & 18.3 \\
\hline
\end{tabular}

Table A 1.7. Regression equations for in vitro fungicide assays Fof 19 day 34 (Table 2.2)

\begin{tabular}{|c|c|c|c|}
\hline Fungicide & Transformation & Equation & r-squared \\
\hline Tebuconazole & $100-Y 5$ by $\log _{10}$ rate & $\mathrm{EC}$ value $=52.98+27.71$ lograte & 96.2 \\
\hline Metconazole & $100-Y 5$ by $\log _{10}$ rate & $\mathrm{EC}$ value $=71.11+26.62$ lograte & 86.4 \\
\hline Flutriafol & $100-Y 5$ by $\log _{10}$ rate & EC value $=24.72+18.88$ lograte & 79.4 \\
\hline Penthiopyrad & $100-Y 5$ by $\log _{10}$ rate & $\mathrm{EC}$ value $=12.15+7.461$ lograte & 87.8 \\
\hline Fluopyram & $100-\mathrm{Y}^{2}$ by rate & $\mathrm{EC}_{\text {value }}^{2}=0.1058+0.4364$ rate & 82.3 \\
\hline Flutolanil & $100-$ Y 5 by $\log _{10}$ rate & $\mathrm{EC}$ value $=8.056+4.189$ lograte & 55.1 \\
\hline Fludioxonil & $100-Y 5^{2}$ by $\log _{10}$ rate & $\mathrm{EC}$ value $=5.745+0.2106$ lograte & 33 \\
\hline
\end{tabular}


Table A 1.8. Regression equations for in vitro fungicide assays Fof 19 day 50 (Table 2.2)

\begin{tabular}{|c|c|c|c|}
\hline Fungicide & Transformation & Equation & r-squared \\
\hline Tebuconazole & $100-Y 5$ by $\log _{10}$ rate & $\mathrm{EC}$ value $=53.81+28.04$ lograte & 95.7 \\
\hline Metconazole & $100-Y 5$ by $\log _{10}$ rate & $\mathrm{EC}$ value $=71.02+26.62$ lograte & 86.6 \\
\hline Flutriafol & $100-Y 5$ by $\log _{10}$ rate & $\mathrm{EC}$ value $=25.56+19.84$ lograte & 77.9 \\
\hline Penthiopyrad & $100-Y 5$ by $\log _{10}$ rate & $\mathrm{EC}$ value $=12.15+7.461$ lograte & 87.8 \\
\hline Fluopyram & $100-\mathrm{Y} 5$ by rate & $\mathrm{EC}_{\text {value }}^{2}=0.1058+0.4364$ rate & 82.3 \\
\hline Flutolanil & $100-Y 5$ by $\log _{10}$ rate & $\mathrm{EC}$ value $=8.056+4.189$ lograte & 55.1 \\
\hline Fludioxonil & $100-Y 5^{2}$ by $\log _{10}$ rate & $\mathrm{EC}$ value $=5.745+0.2106$ lograte & 33.4 \\
\hline
\end{tabular}




\section{Appendix B. Variance Tables for In Planta Fungicide Studies}

\section{B 1. Variance tables for in planta CFU counts}

Table B 1.1. ANOVA for CFU counts $M p$ trial I week 1 (Table 2.4)

\begin{tabular}{lccccc}
\hline \multicolumn{1}{c}{ Source } & DF & SS & MS & F & P \\
\hline Block & 2 & 72584 & 36292 & 15.46 & 0.000 \\
Treatment & 24 & 105558 & 4398 & 1.78 & 0.032 \\
Error & 48 & 112692 & 2348 & & \\
Total & 74 & 290833 & & & \\
\hline
\end{tabular}

Table B 1.2. ANOVA for CFU counts $M p$ trial I week 3 (Table 2.4)

\begin{tabular}{lccccc}
\hline \multicolumn{1}{c}{ Source } & DF & SS & MS & F & P \\
\hline Block & 2 & 1711.1 & 855.56 & 52.15 & 0.000 \\
Treatment & 24 & 5105.4 & 212.73 & 12.97 & 0.000 \\
Error & 48 & 787.5 & 16.41 & & \\
Total & 74 & 7604.1 & & & \\
\hline
\end{tabular}

Table B 1.3. ANOVA for in CFU counts $M p$ trial II week 1 (Table 2.4)

\begin{tabular}{lccccc}
\hline \multicolumn{1}{c}{ Source } & DF & SS & MS & F & P \\
\hline Block & 2 & 16743 & 8371.3 & 13.6 & 0.000 \\
Treatment & 24 & 30265 & 1261 & 2.05 & 0.017 \\
Error & 48 & 29544 & 615.5 & & \\
Total & 74 & 76552 & & & \\
\hline
\end{tabular}

Table B 1.4. ANOVA for CFU counts $M p$ trial II week 3 (Table 2.4)

\begin{tabular}{lccccc}
\hline \multicolumn{1}{c}{ Source } & DF & SS & MS & F & P \\
\hline Block & 2 & 922.6 & 461.3 & 3.26 & 0.047 \\
Treatment & 24 & 8782.3 & 365.9 & 2.59 & 0.003 \\
Error & 48 & 6652.8 & 141.5 & & \\
Total & 74 & 16696.8 & & & \\
\hline
\end{tabular}

Table B 1.5. ANOVA for in CFU counts Fof trial I week 1 (Table 2.4)

\begin{tabular}{lccccc}
\hline \multicolumn{1}{c}{ Source } & DF & SS & MS & F & P \\
\hline Block & 1 & 28.88 & 28.88 & 0.59 & 0.451 \\
Treatment & 24 & 1440.25 & 60.01 & 1.22 & 0.316 \\
Error & 24 & 1181.37 & 49.22 & & \\
Total & 49 & 2650.5 & & & \\
\hline
\end{tabular}

Table B 1.6. ANOVA for CFU counts Fof trial I week 3 (Table 2.4)

\begin{tabular}{lccccc}
\hline \multicolumn{1}{c}{ Source } & DF & SS & MS & F & P \\
\hline Block & 2 & 0.14 & 0.07 & 0.04 & 0.958 \\
Treatment & 24 & 36.83 & 1.53 & 0.95 & 0.541 \\
Error & 48 & 77.53 & 1.62 & & \\
Total & 74 & 114.5 & & & \\
\hline
\end{tabular}




\section{B 2. Variance tables for in planta AUDPC analysis}

Table B 2.1. ANOVA with in block ranked AUDPC for $M p$ trial II (Figure 2.3)

\begin{tabular}{lccccc}
\hline \multicolumn{1}{c}{ Source } & DF & SS & MS & F & P \\
\hline Block & 5 & 0.00 & 0.00 & 0.00 & 1.000 \\
Treatment & 24 & 3221.5 & 134.229 & 3.62 & 0.000 \\
Error & 120 & 4447.5 & 37.063 & & \\
Total & 149 & 7669 & & & \\
\multicolumn{7}{l}{} \\
\multicolumn{7}{c}{ Table B 2.2. ANOVA for } & AUDPC for & Fof trial I (Figure 2.4) & & \\
\hline \multicolumn{7}{c}{ Source } & DF & SS & MS & F & P \\
\hline Block & 4 & 4787476 & 1196869 & 1.19 & 0.320 \\
Treatment & 24 & 120372691 & 5015529 & 4.99 & 0.000 \\
Error & 96 & 96526257 & 1005482 & & \\
Total & 124 & 221686424 & & & \\
\hline
\end{tabular}




\section{Appendix C. Data Analysis for Plant Extract Studies}

\section{1. Variance tables for in vitro germination study}

Table C 1.1. ANOVA using square root transformation germinated microsclerotia (Figure 3.2)

\begin{tabular}{lccccc}
\hline \multicolumn{1}{c}{ Source } & DF & SS & MS & F & P \\
\hline Treatment & 6 & 833.79 & 138.964 & 177.72 & 0.000 \\
Block & 5 & 4.6 & 0.92 & 1.18 & 0.319 \\
\# of Drenches & 1 & 5.9 & 5.90 & 7.55 & 0.006 \\
Trial & 1 & 9.9 & 9.94 & 12.71 & 0.000 \\
Error & 238 & 186.1 & 0.78 & & \\
Total & 251 & 1040.34 & & & \\
\hline
\end{tabular}

\section{2. Main effects plot for in vitro germination study}

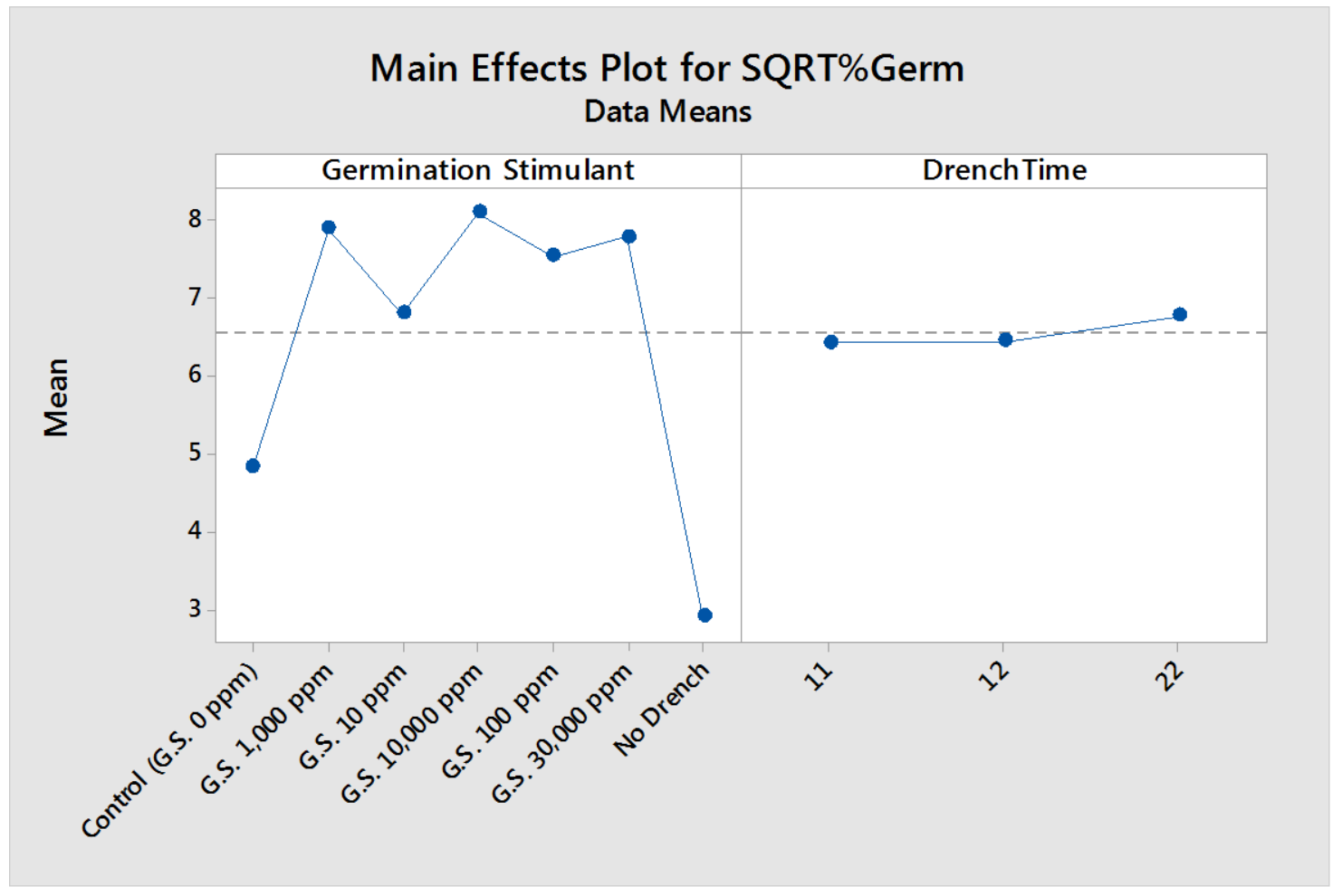




\section{3. Variance tables for in planta germination studies}

Table C 3.1. ANOVA using square root transformation germinated microsclerotia (Figure 3.3, Table 3.3)

\begin{tabular}{lccccccc}
\hline \multicolumn{1}{c}{ Source } & DF & Seq SS & Contribution & Adj SS & MS & F & P \\
\hline Treatment & 6 & 384.47 & $83.24 \%$ & 384.47 & 64.08 & 250.16 & 0.000 \\
\# Drenches & 1 & 357 & $0 \%$ & 357 & 357.1 & 3.11 & 0.080 \\
Drench Time & 2 & 40.80 & $8.83 \%$ & 40.80 & 20.40 & 79.64 & 0.000 \\
Treatment* Drench Time & 12 & 9.73 & $2.11 \%$ & 9.73 & 0.81 & 3.17 & 0.001 \\
Error & 105 & 26.90 & $5.82 \%$ & 26.90 & 0.26 & & \\
Total & 125 & 461.89 & $100.00 \%$ & & & & \\
\hline
\end{tabular}

Table C 3.2. ANOVA using square root transformation germinated microsclerotia integrated trial (Figure 3.5, Table 3.4)

\begin{tabular}{lccccccc}
\hline \multicolumn{1}{c}{ Source } & DF & Seq SS & Contribution & Adj SS & MS & F & P \\
\hline Treatment & 2 & 92.56 & $35.74 \%$ & 85.04 & 42.52 & 404.12 & 0.000 \\
Drench Time & 1 & 97.68 & $37.71 \%$ & 142.25 & 142.25 & 1351.92 & 0.000 \\
Treatment* Drench Time & 2 & 64.54 & $24.92 \%$ & 64.54 & 32.27 & 306.67 & 0.000 \\
Error & 40 & 4.21 & $1.63 \%$ & 4.21 & 0.11 & & \\
Total & 45 & 258.98 & $100.00 \%$ & & & & \\
\hline
\end{tabular}

